\title{
Estimate of the Antifungal Activity and Phytotoxicity of ZnO Nanoparticles on Magnaporthe oryzae and Rice Cultivar Sakha 101 using Morphological, Biochemical and Molecular Markers
}

Elamawi，R.M.A ${ }^{1}$; Youssef，M.S ${ }^{2}$ and EL-Refaee, Y.Z $\mathbf{Z}^{3}$

1. Rice Pathology Department, Plant Pathology Research Institute, Agricultural Research Center, 33717, Sakha, Kafrelsheikh, Egypt.

2. Botany Department, Faculty of Science, Kafrelsheikh University, 33516, Kafrelsheikh, Egypt.

3. Rice Research Department, Field Crops Research Institute, Agricultural Research Centre, 33717, Kafrelsheikh, Egypt.

R ice blast caused by Magnaporthe oryzae is the major biotic stress Rinfluences rice yield. The current investigation aimed to estimate the antifungal activity and phytotoxicity effect of different concentrations of $\mathrm{ZnO}$ nanoparticles $(0.0,10,25,50,100$ and 200 $\mathrm{mg} / \mathrm{L}$ ) on $M$. oryzae and rice cultivar Sakha101 using morphological, biochemical and molecular markers. Five ISSR markers and seven RAPD primers were utilized to estimate the potentiality effects of $\mathrm{ZnO}$ nanoparticles (NPs). The effect of different rates and applications of $\mathrm{ZnO}$ NPs used to control rice blast disease and improve grain yield were estimated in the field during 2017 and 2018 growing seasons. The results showed that, in vitro antifungal assay of ZnO NPs showed a significant decrease in colony formation in comparison to control. Foliar application of $\mathrm{ZnO} \mathrm{NPs}$ at $25 \mathrm{mg} / \mathrm{L}$ was the most effective treatments for mitigation rice blast at five days before inoculation. While under field conditions, foliar spray with $25 \mathrm{mg} / \mathrm{L}$ at nursery increased the grain yield to 4.366 ton/fed in season 2017 and to 4.625 ton/fed in 2018. Foliar spray with ZnO NPs of rice offer a practical and useful approach to improve rice grain yield and reduce leaf blast disease when applied at optimal concentrations. ZnO NPs at lower concentrations (10 and $25 \mathrm{mg} / \mathrm{L})$ enhanced seed germination and improved seedling growth, while the higher concentrations (100 and $200 \mathrm{mg} / \mathrm{L}$ ) resulted in phytotoxicity. ZnO NPs treatments altered the expression patterns of seeds storage protein; induced newly synthesized isoforms and disappearance of existing ones. The obtained results using molecular markers confirmed that the lower concentrations of $\mathrm{ZnO}-\mathrm{NPs}$ (10 and $25 \mathrm{mg} / \mathrm{L}$ ) are considered as a good enhancement agent, as in case of rice cultivar Sakha101, using UBC 825 primer with $306 \mathrm{bp}$ at concentration of $25 \mathrm{mg} / \mathrm{L}$ and OPA-9 primer with $948 \mathrm{bp}$ at concentration of $10 \mathrm{mg} / \mathrm{L}$. For M. oryzae the 
same trend of effects was appeared in case of UBC 880 primer with $994 \mathrm{bp}$ at concentration of $25 \mathrm{mg} / \mathrm{L}$ and OPO-10 primer with $268 \mathrm{bp}$ at concentration of $10 \mathrm{mg} / \mathrm{L}$. In general, these results suggested that lower concentrations of $\mathrm{ZnO}$ NPs could be applied as an effective nano fertilizer for sustainable agriculture and food safety, and moreover, utilized as antifungal agent for rice blast disease.

Keywords: Zinc oxide nanoparticles, Magnaporthe oryzae, Oryza sativa, Phytotoxicity, RAPD and ISSR markers and grain yield.

Agriculture sector faces various and unprecedented challenges, such as reduced crop yields due to biotic and abiotic stresses, including nutrient deficiency and pathogenic microbes, the development of nanotechnology has offered propitious applications for sustainable agriculture. The use of nanoparticles to improve plant growth and for the control of plant diseases is a recent practice (Rastogi et al., 2019). However, phytotoxicity due to exposure to NPs is an unresolved issue. Recent studies showed a strong attempt to understand the effect of nanoparticles on plant growth (Youssef and Elamawi 2018) suggested a positive impact of NPs on plant development with the potential to be used as future Nano-fertilizer.

Rice (Oryza sativa $\mathrm{L}$.) is one of the most important food for more than half of the world; accordingly, its production should be doubled by 2050 to meet the rising global demand (FAO 2009). It is also considered as the main food for all human ages because of its seed's richness in proteins, minerals, vitamins and fibers.

Rice blast is caused by Magnaporthe oryzae Couch (anamorph: Pyricularia oryzae Cavara) (Couch and Kohn 2002). M. oryzae occurs in about 80 countries and attacks over 50 grass species (Ou 1985) It is responsible for approximately losses of 10-30\% of worldwide rice production (Nalley et al., 2016). Most of the rice cultivars are susceptible to different fungus races. Fungicides are commonly used to control blast; however, these are becoming less acceptable as they increase the potential for build-up of resistance in M. oryzae to fungicides and also conflict with the public concern for fungicide residues on human health and environment. The fungus is highly variable so disease control is a challenge (Ou 1985).

Nanoparticles could be used as alternative methods to control this disease. Silver nanoparticles applied effectively in the control of rice blast and the prevention of deleterious infections in rice as reported by (Young et al., 2009; Elamawi and ElShafey 2013 and Elamawi et al., 2018) Several researchers reported the antifungal activity by $\mathrm{ZnO} \mathrm{NPs}$ on numerous fungi species; i.e. (He et al., 2011; Gunalan et al., 2012; Wani and Shah 2012; Savi et al., 2013; Elamawi et al., 2016 and SierraFernandez et al., 2017). To our knowledge, there are no reports about using $\mathrm{ZnO}$ NPs for control of M. oryzae.

Egypt. J. Phytopathol., Vol. 47, No. 1 (2019) 
Zinc is an essential micronutrient element for rice growth. It is indispensable for biochemical processes in rice crop such as nucleotide and cytochrome synthesis, metabolism of auxin, production of chlorophyll, enzymes activity and membrane integrity (Kirk and Bajita 1995). The zinc oxide nanoparticles are used as fertilizer (Singh et al., 2013). ZnO NPs on the form of nanoparticles may increase its availability to plants so its application as a fertilizer may enhance rice growth over the regular $\mathrm{Zn}$ fertilizer. Foliar application of $\mathrm{Zn}$ fertilizer improved both productivity and grain $\mathrm{Zn}$ concentration in rice (Kulhare et al., 2017).

$\mathrm{ZnO}$ is considered to be a "GRAS" (generally recognized as safe) substance by the FDA (2011). The GRAS classification, however, most commonly refers to materials in the micron to a broader range of size, as even such substances can develop toxicity when reduced to the nanoscale (Rasmussen et al., 2011). Consequently, a detailed evaluation of $\mathrm{ZnO}$ NPs toxicity in both in vitro and in vivo systems is needed, as well as identifying means to reduce unwanted toxicity. Phytotoxicity of ZnO NPs on seed germination and root development has been studied in different plant species including; lettuce, radish, and cucumber (Lin and Xing 2007). ZnO NPs reduced biomass, shrunk root tip and epidermis, and cortical cells became highly vacuolated and collapsed on ryegrass (Lin and Xing 2008). Toxicity of ZnO NPs to rice seedlings was evident and increased with increasing concentration of ZnO NPs (more than $250 \mathrm{mg} / \mathrm{L}$ ) (Chen et al., 2015). On the other hand, ZnO NPs promoted seed germination, root and shoot length in the peanut (Prasad et al., 2012). ZnO NPs in lower concentration increased seed germination in wheat (Zhu et al., 2019). Cyamopsis tetragonoloba when exposed to ZnO NPs, showed improved plant biomass, root and shoot length, chlorophyll and protein synthesis and other growth parameters (Raliya and Tarafdar 2013). Lower concentrations of $\mathrm{ZnO}$ NPs (10 and $25 \mathrm{mg} / \mathrm{L})$ enhanced seed germination and improved seedling growth, while higher concentrations (100 and $200 \mathrm{mg} / \mathrm{L})$ resulted in phytotoxicity in the Vicia faba (Youssef and Elamawi 2018).

Recently, studies on the genotoxic effects of NPs on plants are appearing. Genotoxicity describes the property of chemical agents that damage the genetic information within a cell causing mutations, induced by nanoparticles in plants (Remédios et al., 2012). Randomly amplified polymorphic DNA-polymerase chain reaction (RAPD-PCR) is used for DNA analysis in the field of genotoxicity in different plants as a sensitive method, capable of detecting variations in genome profiles (Kekec et al., 2010). The genotoxic and phytotoxic studies represent that $\mathrm{ZnO}$ at $2000 \mathrm{mg} / \mathrm{l}$ effects on buckwheat (Fagopyrum esculentum) seedling (Lee et al., 2013)

The objectives of the present investigation are to evaluate the impacts of $\mathrm{ZnO}$ nanoparticles on $M$. oryzae and $O$. sativa using morphological, biochemical and molecular markers. In addition, to study the potentiality effects of different rates and 
applications of $\mathrm{ZnO}$ NPs as nano-fertilizer and anti-fungal agent to control rice blast disease and improve grain yield of rice cultivar Sakha101.

\section{Materials and Methods}

\subsection{Preparation of $\mathrm{ZnO}$ nanoparticle:}

The $\mathrm{ZnO}$ nanopowder (M K Impex Corp Mississauga, Canada) with primary diameter of $30 \mathrm{~nm}$ was used to prepare five different concentrations of ZnO NPs (10, $25,50,100$, and $200 \mathrm{mg} / \mathrm{L}$ ). The preparation and characterization of $\mathrm{ZnO}$ NPs suspension were fully described in previous paper (Youssef and Elamawi 2018).

\subsection{Biological materials:}

Rice seeds of Oryza sativa cv. Sakha 101 were obtained from Rice Research and Training Center, Kafrelsheikh, Egypt. Rice blast fungus was isolated from infected leaves of Sakha101 rice cultivar from Kafrelsheikh governorate and identified as $M$. oryzae race ID-15 according to disease reaction pattern on the international differential varieties (Atkins et al., 1967).

\subsection{Estimate of antifungal activity of $\mathrm{ZnO} N P$ s against rice blast:}

Three different experiments were conducted to assess the potential application of $\mathrm{ZnO} \mathrm{NPs}$ as antifungal agent and to improve rice productivity under $M$. oryzae infection.

\subsubsection{In Vitro Antifungal Assay of ZnO NPs:}

The antifungal activity of $\mathrm{ZnO}$ NPs against $M$. oryzae was examined based on colony formation test and sporulation capacity according to a modified method of (Jo et al., 2009). Briefly, conidia were collected from M. oryzae culture grown on Banana Dextrose Agar (BDA) medium and incubated at $25^{\circ} \mathrm{C}$ for 10 days. Conidial suspension was diluted with sterile distilled water to a concentration of 106 spores $/ \mathrm{ml}$. $500 \mu \mathrm{l}$ of the conidial suspension were mixed with different concentrations of ZnO NPs $(0.0,10,25,50,100$ and 200) to a final volume of $1 \mathrm{ml}$ per each treatment. All treatments were incubated at $28^{\circ} \mathrm{C}$ for $24 \mathrm{~h}$. then, $50 \mu \mathrm{l}$ aliquot of each treatment were spread on BDA and incubated at $28^{\circ} \mathrm{C}$. The developed colonies were counted after 2, 4 and 6 days of incubation according to Elamawi and El-Shafey (2013). Each treatment was replicated three times. The Sporulation capacity was estimated by adding $10 \mathrm{ml}$ of distilled water to each Petri dish, and then the spores were harvested by spatula. The number of spores $/ \mathrm{ml}$ was counted using the hemocytometer.

2.3.2. Assay of $\mathrm{ZnO} N P s$ capacity for controlling rice blast under artificial inoculation:

In the current investigation, $\mathrm{ZnO}$ NPs capacity for controlling rice blast on Sakha 101 cultivar was estimated under greenhouse conditions. Three protocols and six different $\mathrm{ZnO}$ NPs concentrations (0.0, 10, 25, 50, 100 and $200 \mathrm{mg} / \mathrm{L}$ ) were applied. The first protocol included soaking of rice seeds in the desired solutions for $48 \mathrm{~h}$, the

Egypt. J. Phytopathol., Vol. 47, No. 1 (2019) 
second one involved foliar treatment for seedling with $\mathrm{ZnO}$ NPs five days before inoculation (DBI) with spores of $M$. oryzae. While, the third protocol for foliar treatment of rice seedling was carried out five days post inoculation (DPI). All protocols included inoculation of seedlings (21 days old) with spore suspension of M. oryzae at $1 \times 10^{5}$ spore $/ \mathrm{ml}$ conc. Meanwhile, plants sprayed with water were kept as control for comparison. The inoculated seedlings were held in a moist chamber for $24 \mathrm{~h}$ and then moved to the greenhouse with at least $90 \% \mathrm{R} . \mathrm{H}$. and $25-28^{\circ} \mathrm{C}$. The experiments were performed twice with three replicates for each treatment. Seven days after inoculation, the reaction was scored using the (0-9) scale of IRRI Standard evaluation system (Anon, 2013). Severity of infection was estimated by counting the total number of type (4) or more of blast lesions of 100 randomly selected leaves per pot.

\subsubsection{Effect of ZnO NPs on rice blast and rice grain yield under field conditions:}

For evaluating the ability of $\mathrm{ZnO}$ NPs to control rice blast as well as improving rice grain yield under natural rice blast infection, four protocols with three $\mathrm{ZnO}-\mathrm{NPs}$ concentrations $(25,50$ and $100 \mathrm{mg} / \mathrm{L})$ were applied on susceptible rice cultivar Sakha 101. In the first protocol rice seeds were soaked in $\mathrm{ZnO}$ nanofluid for $48 \mathrm{~h}$. The second protocol involved foliar application of $\mathrm{ZnO}$ nanofluid on rice seedlings at nursery (20 days age). While, in the third protocol foliar spray of $\mathrm{ZnO}$ nanofluid was carried out at 25 days post transplanting (DPT). Finally, foliar spray with selected $\mathrm{ZnO}$ concentrations at 25 DPT followed by a second spray at 50 DPT was the fourth tested protocol. Tricyclazole (Beam $75 \% \mathrm{WP}$ ) as a recommended fungicide for competing rice blast was applied as positive control as well as untreated plants as a negative control for comparison. Thirty days old seedlings were transplanted by four seedlings/hill in a distance of $20 \times 20 \mathrm{~cm}$. The experiments were designed in random complete block design with three replicates during 2017 and 2018 growing seasons at Rice Research and Training Center Research Farm at Sakha Agricultural Research Station, Egypt. Before transplanting, land was prepared as follow; Phosphorous fertilizer (21 kg P2O5/fed) and potassium sulphate $(24 \mathrm{~kg}$ $\mathrm{K} 2 \mathrm{O} / \mathrm{fed}$ ) were applied basally at tillage stage. Nitrogen fertilizer in the form of Urea at the rate of $69 \mathrm{~kg} \mathrm{~N} / \mathrm{fed}$ was applied in two equal doses at; land preparation and 30 days after transplanting (DAT). The rest of management issues were typically followed according to Rice Research and Training Center recommendations. Severity of infection was estimated by counting the total number of type (4) or more of blast lesions/100 leaves.

2.4. Phytotoxicity evaluation of ZnO NPs using germination and seedling vigour testing:

Rice seeds were immersed in a $10 \%$ sodium hypochlorite solution for $10 \mathrm{~min}$ to ensure surface sterility, followed by rinsing three times with distilled water. Then the seeds were allowed to sprout on filter paper saturated with the tested concentrations of $\mathrm{ZnO} N P$ s or distilled water as a control at $25 \pm 2^{\circ} \mathrm{C}$. Three replicates with 25 seeds/dish were applied. Germination percentages were calculated after 10 
days of treatment according to the equation: Seed germination $(\%)=($ Number of germinated seeds/ Number of total seeds) $\times 100$. Seedling vigor parameters including; shoot length, root length and seedling vigor index (VI) were recorded after 20 days. VI was calculated according to Dhindwal et al. (1991) as VI $=$ (shoot length + root length) $\mathrm{x}$ germination percentage.

\subsection{Effect of $\mathrm{ZnO} N P$ s on rice seeds protein PAGE analysis:}

Rice seeds of variety Sakha 101 were soaked for $48 \mathrm{~h}$ in the desired concentrations of $\mathrm{ZnO}$ NPs. Then protein was extracted by homogenizing $100 \mathrm{mg}$ from treated and untreated seeds with $1000 \mu$ l sodium phosphate buffer (PH 7.2), including 2\% sodium dodecyl sulfate (SDS) Dhindwal et al., (1991). The extracts were centrifuged at $10000 \mathrm{rpm}$ for $20 \mathrm{~min}$. The supernatant was kept at $-20^{\circ} \mathrm{C}$ until use. Then $50 \mu \mathrm{l}$ of each sample were combined with the same sample buffer volume containing $0.125 \mathrm{M}$ Tris/Hcl, $\mathrm{pH} 6.8,2 \%$ (w/v) SDS, $10 \%$ sucrose, $1 \%(\mathrm{v} / \mathrm{v}) \beta$ mercapto-ethanol and $0.15(\mathrm{~m} / \mathrm{v})$ bromophenol blue followed by heat denaturation at $100^{\circ} \mathrm{C}$ for 4 minutes. One dimensional SDS-PAGE of extracted proteins was carried out in a vertical slab gel using $12.5 \%$ (w/v) acrylamide according to Laemmli (1970). A volume of $40 \mu \mathrm{l}$ was loaded in each well. In addition, $10 \mu \mathrm{l}$ of a protein ladder ranging from 150 to $20 \mathrm{kDa}$ (Thermo Fisher Scientific, Waltham, MA, USA) were loaded to allow the detection of the molecular weights of the separated proteins. Electrophoresis was carried out (using BioRad protean ${ }^{\circledR}$ II $\mathrm{x}$ i cell vertical slab gel unit) at constant voltage of $100 \mathrm{v}$ and $50 \mathrm{~mA}$, until the bromophenol blue dye reached the bottom of the gel. The gel was directly placed in commassie brilliant blue R250 staining solution for $4 \mathrm{~h}$ and distained several times using the distaining solution until bands become clear. The gel was then visualized in white fluorescent light and photographed. The molecular weights of the produced bands by each sample, were calculated using the Lab Image Software version 2.7 program and then were compared with those of other treatments (Laemmli, 1970).

\subsection{Detection effect of $\mathrm{ZnO} N P$ s using ISSR and RAPD-PCR primers}

2.6.1. Extraction and purification of genomic DNA:

Seeds of rice cultivar Sakha101 were germinated and grown for two weeks on filter papers saturated with the desired $\mathrm{ZnO}$ NPs suspensions. Leaves representing at least three different plants per each treatment were grinded to a fine powder using liquid nitrogen, a porcelain mortar and pestle. Then $100 \mathrm{mg}$ of the powder were transferred to pre warmed cetyltrimethyl ammonium bromide (CTAB) extraction buffer and incubated for $30 \mathrm{~min}$ at $65^{\circ} \mathrm{C}$. The total genomic DNA was isolated in accordance with the methods adopted by Clarke (2009), and the modifications done by Saad-Allah and Youssef (2018). In case of M. oryzae, the protocol mentioned before was effective in extracting genomic DNA from $50 \mathrm{mg}$ of its hyphae. Firstly, the isolate of $M$. oryzae was inoculated into $50 \mathrm{ml}$ liquid medium of potato dextrose containing the desired concentration of $\mathrm{ZnO} N P s(0.0,10,25,50,100,200 \mathrm{mg} / \mathrm{L})$ at $28^{\circ} \mathrm{C}$ in orbital shaker $(120 \mathrm{rpm})$. The fresh mycelia mass of each treatment was harvested after two weeks of incubation using Whatman filter paper No. 3 and Egypt. J. Phytopathol., Vol. 47, No. 1 (2019) 
immediately frozen in the liquid nitrogen. The frozen mycelia were ground into a fine powder using a sterile pestle and mortar. The mycelia powder was stored at $20^{\circ} \mathrm{C}$ until needed for DNA extraction. The DNA concentration and purity were determined by a Nanodrop ND-1000 spectrophotometer. The 260/280 absorption ratio ranged from 1.7 to 1.8 , which indicates DNA purity. For molecular screening of potentiality effects of nano-ZnO, five ISSR and seven RAPD-PCR primers were used (Saad-Allah and Youssef, 2018). The details of the selected primers are listed in Table (1).

Table (1): List of ISSR and RAPD-PCR primers used for screening the effect of ZnO NPs on Magnaporthe oryzae and rice cultivar Sakha101

\begin{tabular}{clc}
\hline No. & Primer code & Sequence $\left.\mathbf{5}^{\prime}-\mathbf{3}^{\prime}\right)$ \\
\hline & & ISSR primers \\
\hline 1 & UBC 825 & ACACACACACACACACT \\
3 & UBC 845 & CTCTCTCTC TCT CTC TGG \\
4 & UBC 857 & ACA CAC ACA CAC ACA CTG \\
5 & UBC 861 & ACCACCACCACCACCACC \\
& UBC 880 & GGAGAGGAGAGGAGA \\
\hline 1 & OPA-9 & GGGTAACGCC \\
2 & OPA-13 & GAGCACCCAC \\
3 & OPB-11 & GTGAGGCGTCG \\
4 & OPC-2 & GGCACTGAGG \\
5 & OPG-2 & TCAGAGCGCC \\
6 & OPO-10 & ACTTTGGCGG \\
7 & OPZ-20
\end{tabular}

$\mathrm{OP}=$ Operon Technologies Almeda, CA. UBC = Primer set \#9. University of British Columbia, CA.

\subsubsection{ISSR markers.}

Five ISSR primers were used as generic primers in the PCR amplification of the ISSR regions in treated and control samples. The amplification mixture $(20 \mu \mathrm{l})$ contained the indicated primers $(1.0 \mu \mathrm{l}), 2 \mu \mathrm{l}$ genomic DNA (100 ng), sterilized double-distilled H2O $(7 \mu \mathrm{l})$ and Dream Taq Green PCR Master Mix \#k 1081 (Thermo Fisher Scientific, UK) $(10 \mu \mathrm{l})$. The thermocycling conditions were as follows: an initial denaturation step for at $94{ }^{\circ} \mathrm{C}$ for $5 \mathrm{~min}$; 40 cycles of $94{ }^{\circ} \mathrm{C}$ for 1 min, $48-52{ }^{\circ} \mathrm{C}$ for $30 \mathrm{~s}$ (based on the primer sequence), and $72{ }^{\circ} \mathrm{C}$ for $1 \mathrm{~min}$; and a final extension step at $72{ }^{\circ} \mathrm{C}$ for $8 \mathrm{~min}$ (Saad-Allah and Youssef, 2018).

\subsubsection{RAPD-PCR:}

Seven random DNA oligonucleotide (10- base) primers were independently used for detection of DNA alteration upon exposure to ZnO NPs using the PCR technique. The PCR amplifications were performed using the indicated primers (1.0 
$\mu 1)$ in a $20 \mu \mathrm{l}$ reaction volume containing genomic DNA (100 ng), sterilized doubledistilled H2O (7 $\mu \mathrm{l})$ and $10 \mu \mathrm{l}$ of Dream Taq Green PCR Master Mix \#k 1081 (Thermo Fisher Scientific, UK). The thermal cycles were as follows: initial denaturation at $94{ }^{\circ} \mathrm{C}$ for $5 \mathrm{~min}$; 40 cycles of $94{ }^{\circ} \mathrm{C}$ for $1 \mathrm{~min}, 37^{\circ} \mathrm{C}$ for $30 \mathrm{~s}$ and 72 ${ }^{\circ} \mathrm{C}$ for $2 \mathrm{~min}$; and a final extension for $8 \mathrm{~min}$ at $72{ }^{\circ} \mathrm{C}$ (Saad-Allah and Youssef, 2018).

2.6.4. Estimate the Amplified DNA fragments and Data Analysis:

After the completion of PCR, $10 \mu \mathrm{l}$ of the PCR-amplified products were electrophoresed using $1.6 \%$ agarose gel in $0.5 \times$ TBE buffer in a submarine gel apparatus at $100 \mathrm{~V}$ for $1 \mathrm{~h}$. The gels were visualized under UV light and imaged using a gel documentation system (CFW- M; Bio-Rad). All reactions were repeated twice, and only reproducible bands were scored. Thermo Scientific Gene-Ruler DNA ladders with a length of $1 \mathrm{~kb}$ or $100 \mathrm{bp}(100 \mathrm{ng} \mu \mathrm{l})$ were used as DNA size standards for detection band size (Saad-Allah and Youssef, 2018).

\subsection{Statistical analysis:}

All data were subjected to statistical analysis according to the procedures reported Kobata et al. (2018). The significance of differences among means was measured by Duncan's multiple range tests at $\mathrm{P}<0.05$. The results expressed as mean $\pm \mathrm{SD}$ of three replicates per each treatment and subjected to one-way analysis of variance (ANOVA) using SPSS v.16 (SPSS, Chicago, USA).

\section{Results}

\subsection{Estimate of antifungal activity of $\mathrm{ZnO} N P$ s under Lab. conditions:}

Effect of $\mathrm{ZnO} \mathrm{NPs}$ on colony formation and spores production of M. oryzae is illustrated in Figure 1. To our knowledge, there is no previous reports discussed the effect of ZnO NPs on M. oryzae. All the studied concentrations of ZnO NPs showed significant decrease in colony formation in comparison to control (Fig. 1A). Although, the growth inhibition under ZnO NPs exposure was not dose-dependent, the lowest numbers of colonies were recorded at 10 and $25 \mathrm{mg} / \mathrm{L} \mathrm{ZnO} \mathrm{NPs} \mathrm{(11.66}$ and 17.00 , respectively). Interestingly, ZnO-NPs treatments accelerated the conidia production compared to control. The highest spore production (45 spore/L) was estimated after exposure to $100 \mathrm{mg} / \mathrm{L}$ ZnO NPs (Fig. 1B).

\subsection{Effect of ZnO NPs on rice leaf blast severity under artificial inoculation:}

The potentiality of the $\mathrm{ZnO}$ NPs to mitigate rice blast is presented in Table (2). Generally, all applied protocols; seed soaking in ZnO NPs solutions, foliar spray at 5 DBI and foliar spray at 5 DPI reduced blast lesions numbers compared to untreated control without noticeable phytotoxicity. Seed soaking and foliar spray at 5 DBI treatments significantly declined the disease severity. The lowest degree of rice blast severity (16 lesions/100 leaves) was obtained by foliar spray with $25 \mathrm{mg} / \mathrm{L} \mathrm{ZnO} \mathrm{NPs}$ at 5 DBI. Results of experiment under greenhouse indicated that foliar application of 
$\mathrm{ZnO}$ NPs at $5 \mathrm{DBI}$ with concentration $25 \mathrm{mg} / \mathrm{L}$ was the most effective treatment for mitigation rice blast without obvious phytotoxicity.
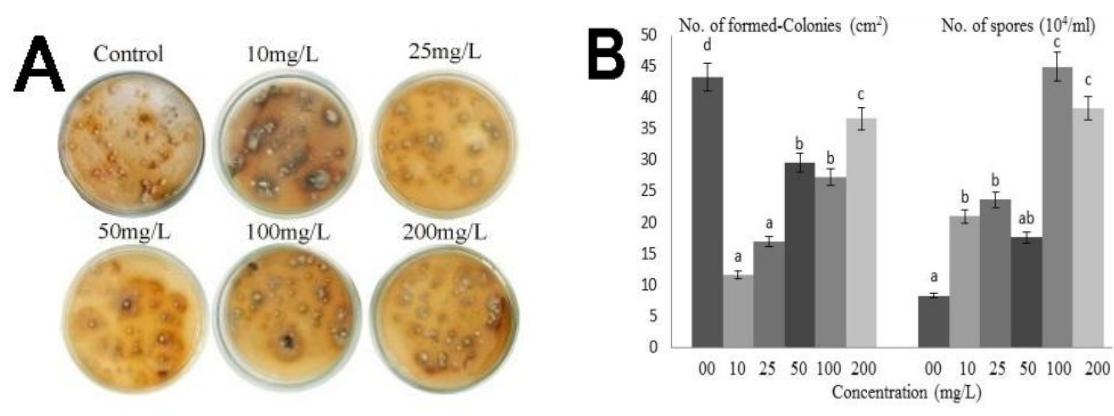

Fig. (1): Effect of $\mathrm{ZnO}$ NPs on colony formation of Magnaporthe oryzae after 7 days on banana dextrose agar medium. (A) Frequency of Number of formed-Colonies $\left(\mathrm{cm}^{2}\right)$, (B) No. of spores/ml

Table (2): Effect of ZnO NPs on rice blast severity on Sakha101 cultivar under greenhouse conditions

\begin{tabular}{lccc}
\hline \multirow{2}{*}{ Concentrations $(\mathrm{mg} / \mathrm{L})$} & \multicolumn{3}{c}{ Severity of infection (No. of lesions/100 leaves) } \\
\cline { 2 - 4 } & Seed Soaking & $5 \mathrm{DBI}$ & $5 \mathrm{DPI} * *$ \\
\hline Control (00) & $37.66 \mathrm{i}$ & $37.66 \mathrm{i}$ & $37.66 \mathrm{i}$ \\
ZnO NP 10 & $21.32 \mathrm{~d}$ & $19.27 \mathrm{c}$ & $27.97 \mathrm{~g}$ \\
ZnO NP 25 & $20.67 \mathrm{~d}$ & $16.00 \mathrm{a}$ & $25.66 \mathrm{f}$ \\
ZnO NP 50 & $18.00 \mathrm{~b}$ & $17.33 \mathrm{~b}$ & $26.33 \mathrm{f}$ \\
ZnO NP 100 & $19.67 \mathrm{c}$ & $22.00 \mathrm{de}$ & $29.00 \mathrm{gh}$ \\
ZnO NP 200 & $28.53 \mathrm{~g}$ & $25.26 \mathrm{f}$ & $30.13 \mathrm{~h}$ \\
\hline \multicolumn{2}{c}{$*$ Treatments: DBI; days before inoculation, **DPI ; days post-inoculation }
\end{tabular}

* Treatments: DBI; days before inoculation, **DPI ; days post-inoculation

\subsection{Effect of ZnO NPs on rice blast and grain yield under field conditions:}

The ability of $\mathrm{ZnO}$ NPs to control rice blast as well as improving rice grain yield under natural rice blast infection is summarized in Table 3. The effect of ZnO NPs on rice blast under field conditions showed the same trend of those recorded in greenhouse experiments. The most powerful $\mathrm{ZnO}$ NPs treatments against rice blast were foliar application with $25 \mathrm{mg} / \mathrm{L}$ at nursery and double spray at $25 \mathrm{DPT}$ followed by 50 DPT. Foliar spray at 25 DPT followed by 50 DPT reduced the disease severity to 8.60 and 9.33 lesions/100 leaves during growing seasons 2017 and 2018, respectively. Foliar spray with $25 \mathrm{mg} / \mathrm{L}$ at nursery declined the disease severity to 9.70 and 10.67 lesions/100 leaves during 2017 and 2018 seasons, respectively. These treatments showed insignificant differences with the recommended fungicide tricyclazole during season 2017. While, during 2018 season, they exhibited low significance. The mean efficiency severity of infection 
was recorded with both treatments spray nursery at 20 days and 25 DPT followed by $50 \mathrm{DPT}$ at $25 \mathrm{mg} / \mathrm{L}(81.0$ and $83.3 \%$, respectively). Consequently, the aforementioned treatments improved grain yield in both seasons. Foliar spray with $25 \mathrm{mg} / \mathrm{L}$ at nursery increased the grain yield to $4366 \mathrm{~kg} / \mathrm{fed}$ in season 2017 and to $4625 \mathrm{~kg} / \mathrm{fed}$ in 2018. While, double foliar spray with $25 \mathrm{mg} / \mathrm{L} \mathrm{ZnO} \mathrm{NPs} \mathrm{at} 25 \mathrm{DPT}$ followed by 50 DPT enhanced grain yield to $4307 \mathrm{~kg} / \mathrm{fed}$ in 2017 seasons and to $4650 \mathrm{~kg} / \mathrm{fed}$ in 2018. The mean grain yield increasing over control (Efficiency \%) has been increased 15.22 and $14.56 \%$ with both treatments at nursery and Two spray at 25DPT + 50DPT with concentration of $25 \mathrm{mg} / \mathrm{L}$, respectively.

Table (3): Effect of ZnO NPs on rice blast severity and grain yield on Sakha101 cultivar under field conditions during 2017 and 2018 growing seasons

\begin{tabular}{|c|c|c|c|c|c|c|c|c|c|}
\hline \multirow[t]{2}{*}{ Treatments } & \multirow{2}{*}{ 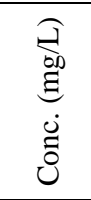 } & \multicolumn{2}{|c|}{$\begin{array}{c}\text { Severity of } \\
\text { infection (No. } \\
\text { of lesions/100 } \\
\text { leaves) }\end{array}$} & \multirow{2}{*}{ 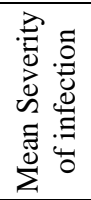 } & \multirow{2}{*}{ 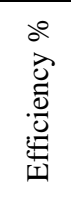 } & \multicolumn{2}{|c|}{$\begin{array}{l}\text { Grain Yield } \\
\text { (kg/fed.) }\end{array}$} & \multirow[t]{2}{*}{$\begin{array}{c}\text { Mean } \\
\text { Grain } \\
\text { Yield } \\
\text { (kg/fed.) }\end{array}$} & \multirow{2}{*}{ 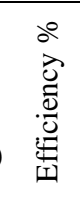 } \\
\hline & & 2017 & 2018 & & & 2017 & 2018 & & \\
\hline \multirow[t]{2}{*}{ Control } & 0.0 & $55.67 \mathrm{i}$ & & 53.67 & - & & & & - \\
\hline & 25 & $15.17 \mathrm{~b}$ & $19.50 \mathrm{ef}$ & 17.34 & 67.7 & $01732 \pi$ & & & 7.14 \\
\hline \multirow[t]{3}{*}{ Seed Soaking } & 50 & $14.17 b$ & $18.67 \mathrm{e}$ & 16.42 & 69.4 & & 448 & & 7.63 \\
\hline & 100 & $22.94 \mathrm{c}$ & $20.77 f$ & 21.86 & 59.3 & $3918.00 \mathrm{~d}$ & $4472.00 \mathrm{~b}$ & & 7.51 \\
\hline & 25 & $9.70 \mathrm{a}$ & $10.67 \mathrm{~b}$ & 10.19 & 81.0 & $4366.33 b$ & $4625.34 \mathrm{a}$ & 4495.83 & 15.22 \\
\hline \multirow{2}{*}{$\begin{array}{l}\text { Spray nursery } \\
\text { at } 20 \text { days }\end{array}$} & 50 & $13.14 b$ & $14.00 \mathrm{c}$ & 13.57 & 74.7 & $4191.00 \mathrm{c}$ & $4496.00 \mathrm{~b}$ & 4343.50 & 11.31 \\
\hline & 100 & $21.17 b c$ & $15.00 \mathrm{~cd}$ & 18.05 & 66.4 & 3988.67d & $4495.14 b$ & 4241.90 & 8.71 \\
\hline \multirow{3}{*}{$\begin{array}{l}\text { One spray at } \\
25 \mathrm{DPT}^{*}\end{array}$} & 25 & $19.00 \mathrm{bc}$ & $20.10 f$ & 19.55 & 63.6 & $3873.33 \mathrm{f}$ & $4394.45 d$ & 4133.89 & 5.94 \\
\hline & 50 & $17.93 \mathrm{bc}$ & $16.57 \mathrm{~d}$ & 17.25 & 67.9 & $3883.33 \mathrm{f}$ & $4371.34 d$ & 4127.33 & 5.77 \\
\hline & 100 & $35.80 \mathrm{~d}$ & $25.67 \mathrm{~h}$ & 30.74 & 42.7 & $3861.00 f$ & $4356.23 d$ & 4108.61 & 5.30 \\
\hline \multirow{3}{*}{$\begin{array}{c}\text { Two spray at } \\
25 \mathrm{DPT}+ \\
50 \mathrm{DPT} *\end{array}$} & 25 & $8.60 \mathrm{a}$ & $9.33 b$ & 8.97 & 83.3 & $4307.00 \mathrm{~b}$ & $4633.00 \mathrm{a}$ & 4470.00 & 14.56 \\
\hline & 50 & $12.23 b$ & $11.33 \mathrm{~b}$ & 11.78 & 78.1 & $4126.67 \mathrm{c}$ & $4650.12 \mathrm{a}$ & 4388.39 & 12.47 \\
\hline & 100 & $26.50 \mathrm{c}$ & $23.33 \mathrm{~g}$ & 24.92 & 53.6 & 3976.67d & $4394.25 d$ & 4185.46 & 7.26 \\
\hline Tricyclazole & $0.5 \mathrm{~g} / \mathrm{L}$ & $6.10 \mathrm{a}$ & $5.33 \mathrm{a}$ & 5.72 & 89.4 & $4510.00 \mathrm{a}$ & $4678.00 \mathrm{a}$ & 4594.00 & 17.73 \\
\hline
\end{tabular}

*DPT; days post transplanting

\subsection{Effect of ZnO NPs on germination and seedling vigor:}

The effect of $\mathrm{ZnO}$ NPs on germination \% and seedling vigor of Sakha 101 rice cultivar is represented in Figure (2). The results showed that increasing ZnO NPs concentration resulted in gradual increase in germination $\%$ followed by gradual decrease. In general, lower conc. of ZnO NPs (especially 10 and $25 \mathrm{mg} / \mathrm{L}$ ) enhanced seed germination. On the other hand, higher conc. $(200 \mathrm{mg} / \mathrm{L})$ showed insignificant effect compared to control treatment (Fig 2A). Visual observation of rice Egypt. J. Phytopathol., Vol. 47, No. 1 (2019) 
germination after three days of treatment showed that ZnO NPs accelerated germination process compared to the control (Fig. 2B). This observation needs more future studies about the influence of $\mathrm{ZnO}$ NPs on metabolic and regulation process of seed germination.

Concerning the root growth for Sakha 101, an obvious increase in root length was recorded as the $\mathrm{ZnO}$ NPs concentration was increased. The root reached the maximum value, $13.00 \mathrm{~cm}$ for Sakha 101 with $25 \mathrm{mg} / \mathrm{L} \mathrm{ZnO} \mathrm{NPs} \mathrm{treatment.} \mathrm{A}$ noticeable inhibition for root growth was detected at $200 \mathrm{mg} / \mathrm{L}$ treatment (8.64) (Fig. 2C).

\section{A}
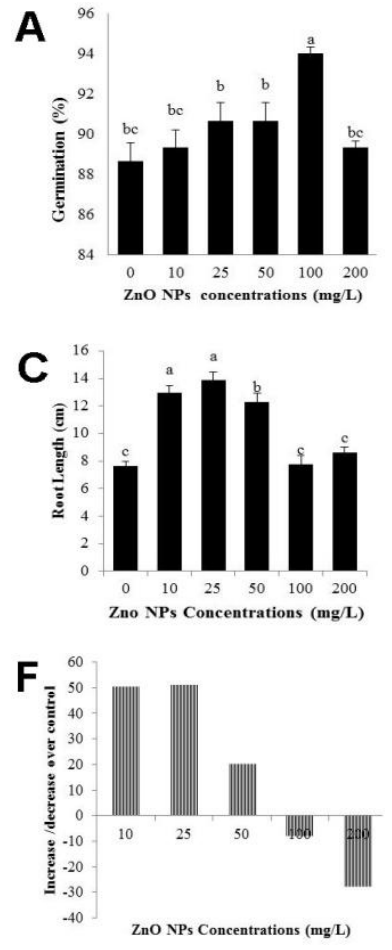
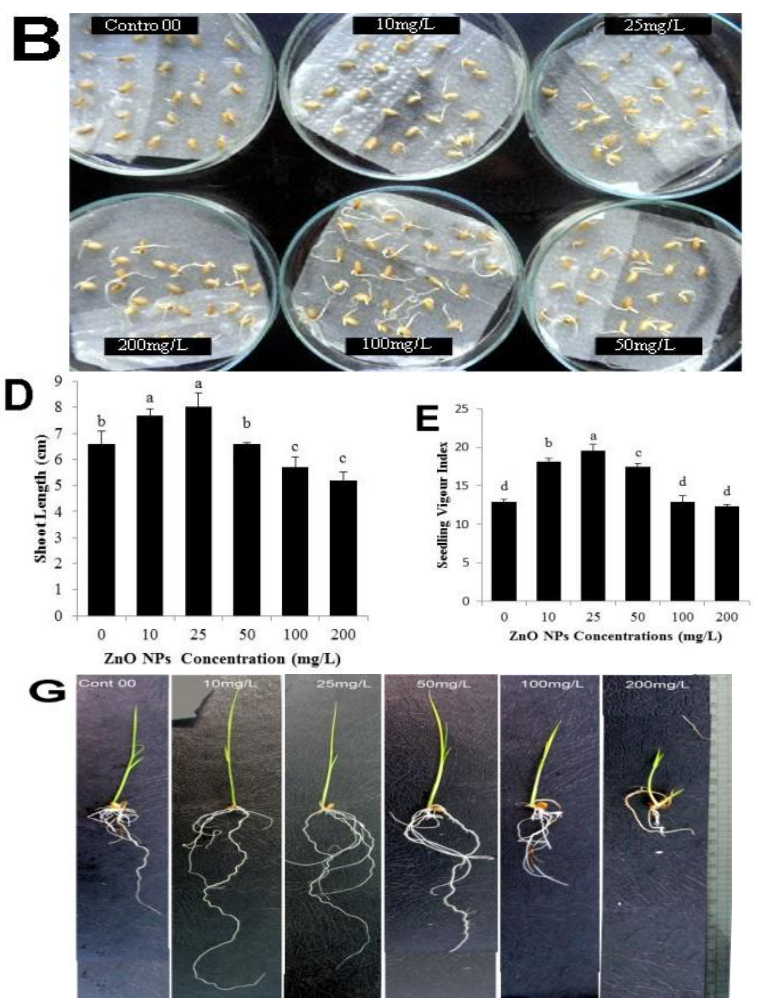

Fig (2): Effect of different concentrations of $\mathrm{ZnO}$ nanoparticles on Sakha 101 rice cultivar. (A) Germination \%, (B) Acceleration of germination after 4 days, (C) Root length (cm), (D) Shoot length (cm), (E) Seedling Vigor Index, (F) Increase/decrease over control related to seedling vigor, (G) Morphological characteristics of the treated seedlings after 20 days post sowing.

Results of the current study indicated an obvious improvement in shoot growth with $25 \mathrm{mg} / \mathrm{L} \mathrm{ZnO} \mathrm{NPs} \mathrm{treatment,} \mathrm{at} \mathrm{which} \mathrm{the} \mathrm{highest} \mathrm{shoot} \mathrm{length} \mathrm{value}(8.03) \mathrm{cm}$ 
was recorded. On the contrary, a great drop in shoot length $(5.21 \mathrm{~cm})$ was detected at $200 \mathrm{mg} / \mathrm{L}$ treatment (Fig. 2D). The beneficial effects of lower-medium levels of $\mathrm{ZnO}$ NPs on seedling establishment were also confirmed using the vigor index, which reached a maximum value at $25 \mathrm{mg} / \mathrm{L} \mathrm{ZnO}$ NPs (Fig. 2E), corresponding to a $100 \%$ increase relative to control conditions (Fig. 2F). At higher ZnO NPs levels, the vigor index (20.36) was gradually declined in a trend similar to that observed for the shoot and root growth (compared to Fig. 2C-D). At a morphological level, plants appeared taller when treated with 10 and $25 \mathrm{mg} / \mathrm{L} \mathrm{ZnO} \mathrm{NPs} \mathrm{(Fig.} \mathrm{2G).} \mathrm{At} \mathrm{the} \mathrm{highest}$ $\mathrm{ZnO}$ NPs concentrations (100 and $200 \mathrm{mg} / \mathrm{L}$ ), the root tips exhibited a dark coloration denoting signs of necrosis. Collectively, these results clearly show the beneficial effects of low-moderate concentrations of $\mathrm{ZnO}$ NPs on plant performance.

3.5. Effect of ZnO NPs on rice cultivar Sakha 101 seeds protein using PAGE analysis:

SDS-PAGE of rice seeds soaked for $48 \mathrm{~h}$ in different concentrations of ZnO NPs gave protein bands with molecular weights ranging from $134 \mathrm{kDa}$ to $21 \mathrm{kDa}$. The total number of scored bands was 22, with 14 bands for control and 15 bands were recorded per each treatment (Table 4). The results showed that, $\mathrm{ZnO}-\mathrm{NPs}$ induced variations in the protein banding pattern between control and treated seeds with 68.2 $\%$ polymorphism. Newly synthesized protein bands had been detected; the treatments from 10 to $100 \mathrm{mg} / \mathrm{L}$ induced the synthesis of the two bands (63 and 60 $\mathrm{KDa}$ ), while the treatment with $200 \mathrm{mg} / \mathrm{L}$ of $\mathrm{ZnO}-\mathrm{NPs}$ induced the synthesis of new six bands $(120,99,89,77,72.61)$ in treated seeds of rice cultivar Sakha 101 (Fig. 3).

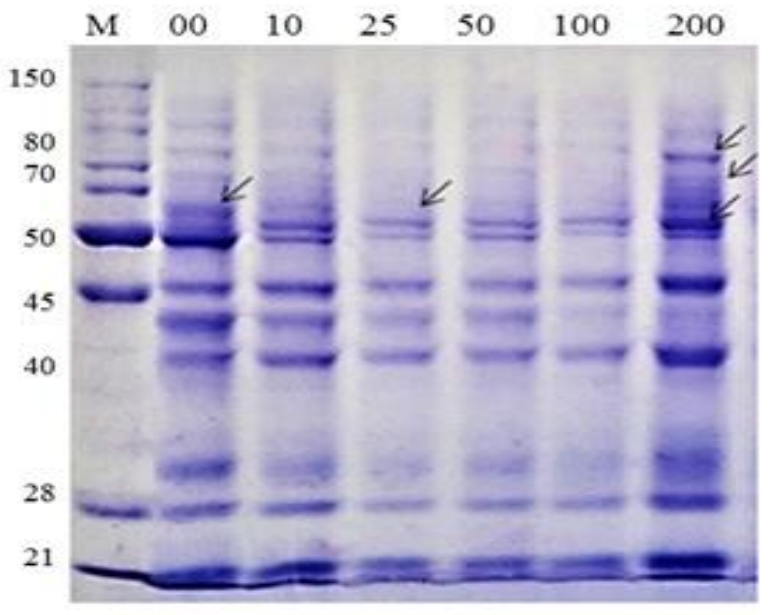

Fig. (3): SDS-PAGE protein patterns of rice in response to different concentrations (mg/L) of $\mathrm{ZnO}$-Nps exposure for $48 \mathrm{hr}$. (M) Protein marker. Arrows point to newly synthesized or appeared bands.

Egypt. J. Phytopathol., Vol. 47, No. 1 (2019) 
The number of polymorphic protein bands varied among treatments. The highest value (11 polymorphic bands) was recorded for $200 \mathrm{mg} / \mathrm{L} \mathrm{ZnO} \mathrm{NPs} \mathrm{treatment}$ showing $55 \%$ polymorphism compared to control, followed by $25 \mathrm{mg} / \mathrm{L}$ (4 polymorphic bands) with $25 \%$ polymorphism (Table 4 ). The other concentrations $(10,50$ and $100 \mathrm{mg} / \mathrm{L})$ showed three polymorphic bands with $18.75 \%$ polymorphism for each.

Table (4): Protein banding pattern of rice cultivar Sakha 101 under different concentrations of $\mathrm{ZnO}$ NPs

\begin{tabular}{|c|c|c|c|c|c|c|c|c|c|}
\hline \multirow{2}{*}{$\begin{array}{c}\text { Band } \\
\text { number }\end{array}$} & \multirow{2}{*}{$\stackrel{\dot{\Sigma}}{\dot{\Sigma}}$} & \multicolumn{6}{|c|}{ ZnO NPs Conc.(mg/L) } & \multirow{2}{*}{$\begin{array}{c}\text { Frequenc } \\
y\end{array}$} & \multirow{2}{*}{ Polymorphic bands } \\
\hline & & 0.0 & 10 & 25 & 50 & 100 & 200 & & \\
\hline 1 & 134 & + & + & + & + & + & - & 0.833 & Polymorphic \\
\hline 2 & 132 & + & + & + & + & + & - & 0.833 & Polymorphic \\
\hline 3 & 120 & - & - & - & - & - & + & 0.166 & Polymorphic \\
\hline 4 & 104 & + & + & + & + & + & - & 0.833 & Polymorphic \\
\hline 5 & 99 & - & - & - & - & - & + & 0.166 & Polymorphic \\
\hline 6 & 91 & + & + & + & + & + & - & 0.833 & Polymorphic \\
\hline 7 & 89 & - & - & - & - & - & + & 0.166 & Polymorphic \\
\hline 8 & 79 & + & + & + & + & + & - & 0.833 & Polymorphic \\
\hline 9 & 77 & - & - & - & - & - & + & 0.166 & Polymorphic \\
\hline 10 & 72 & - & - & - & - & - & + & 0.166 & Polymorphic \\
\hline 11 & 66 & + & + & - & + & + & + & 0.833 & Polymorphic \\
\hline 12 & 63 & - & + & + & + & + & - & 0.666 & Polymorphic \\
\hline 13 & 61 & - & - & - & - & - & + & 0.166 & Polymorphic \\
\hline 14 & 60 & - & + & + & + & + & - & 0.666 & Polymorphic \\
\hline 15 & 59 & + & - & - & - & - & + & 0.333 & Polymorphic \\
\hline 16 & 51 & + & + & + & + & + & + & 1 & Monomorphic \\
\hline 17 & 45 & + & + & + & + & + & + & 1 & Monomorphic \\
\hline 18 & 39 & + & + & + & + & + & + & 1 & Monomorphic \\
\hline 19 & 36 & + & + & + & + & + & + & 1 & Monomorphic \\
\hline 20 & 28 & + & + & + & + & + & + & 1 & Monomorphic \\
\hline 21 & 25 & + & + & + & + & + & + & 1 & Monomorphic \\
\hline 22 & 21 & + & + & + & + & + & + & 1 & Monomorphic \\
\hline \multicolumn{2}{|c|}{ Total No. of bands } & 14 & 15 & 14 & 15 & 15 & 15 & & \\
\hline \multicolumn{2}{|c|}{$\begin{array}{c}\text { Polymorphic } \\
\text { bands/treatment }\end{array}$} & 0 & 3 & 4 & 3 & 3 & 11 & & \\
\hline \multicolumn{2}{|c|}{ Polymorphism \% } & 0.0 & 18.7 & 25 & 18.7 & 18.7 & 55 & & \\
\hline
\end{tabular}

3.6. Effect of ZnO NPs on genomic DNA of Magnaporthe oryzae using ISSR and RAPD-PCR primers:

The genomic DNA of $M$. oryzae was subjected to five ISSR markers and seven RAPD primers in order to determine the effect of the different concentrations of ZnO-NPs used in this study (Table 5 and Figure 4). All ISSR primers amplified and generated polymorphic alleles except UBC 857 which showed monomorphic alleles. 
Meanwhile, out of seven RAPD-PCR primers used in this study, only three primers amplified and generated polymorphic bands.

Table (5): Effect of different concentrations of ZnO NPs on genomic DNA of Magnaporthe oryzae

\begin{tabular}{|c|c|c|c|c|c|c|c|c|c|c|c|c|c|}
\hline \multirow{2}{*}{ 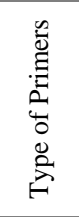 } & \multirow{2}{*}{ 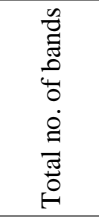 } & \multirow{2}{*}{ 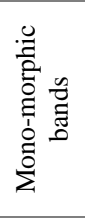 } & \multirow{2}{*}{ 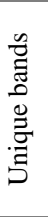 } & \multirow{2}{*}{ 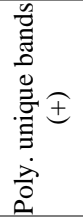 } & \multirow{2}{*}{ 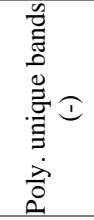 } & \multirow{2}{*}{$\begin{array}{l}\text { Poly. } \\
\%\end{array}$} & \multirow{2}{*}{$\begin{array}{l}\mathrm{Mw} \\
\text { (bp) }\end{array}$} & \multicolumn{6}{|c|}{$\begin{array}{l}\text { Concentrations of ZnO NPs } \\
\qquad(\mathrm{mg} / \mathrm{L})\end{array}$} \\
\hline & & & & & & & & 0 & 10 & 25 & 50 & 100 & 200 \\
\hline \multirow{7}{*}{ 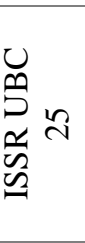 } & 7 & 2 & 2 & 7 & 5 & 100 & 1151 & - & - & - & + & + & - \\
\hline & (1151- & & & & & & 790 & + & + & + & + & + & - \\
\hline & 129) & & & & & & 658 & + & + & + & + & + & - \\
\hline & & & & & & & 233 & + & + & + & + & + & - \\
\hline & & & & & & & 135 & - & - & - & - & + & - \\
\hline & & & & & & & 131 & - & - & - & + & - & - \\
\hline & & & & & & & 129 & + & + & + & - & - & - \\
\hline \multirow{5}{*}{ 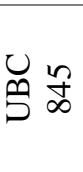 } & 5 & 0 & 1 & 5 & 4 & 100 & 658 & - & - & + & + & + & + \\
\hline & (658- & & & & & & 525 & - & + & + & + & + & + \\
\hline & 153) & & & & & & 335 & - & + & + & + & + & + \\
\hline & & & & & & & 233 & - & + & + & + & + & + \\
\hline & & & & & & & 153 & - & - & - & + & - & - \\
\hline \multirow{4}{*}{$\underbrace{}_{\infty}$} & 7 & 3 & 1 & 4 & 3 & 57.0 & 1175 & + & - & + & + & + & + \\
\hline & (1175- & & & & & & 993 & + & - & + & + & + & + \\
\hline & $300)$ & & & & & & 837 & + & - & + & + & + & + \\
\hline & & & & & & & 300 & + & - & - & - & - & - \\
\hline \multirow{8}{*}{$\begin{array}{l}\infty \\
\infty \\
\cup \\
\wp \\
\emptyset\end{array}$} & 12 & 1 & 7 & 11 & 5 & 91.7 & 1337 & - & - & + & - & - & + \\
\hline & (1337 & & & & & & 1181 & - & - & + & + & + & + \\
\hline & $-399)$ & & & & & & 1171 & + & - & - & - & - & - \\
\hline & & & & & & & 994 & - & - & + & - & - & - \\
\hline & & & & & & & 888 & + & - & - & - & - & - \\
\hline & & & & & & & 541 & - & + & + & + & + & + \\
\hline & & & & & & & 525 & + & - & - & - & - & - \\
\hline & & & & & & & 399 & + & - & - & - & - & - \\
\hline \multirow{5}{*}{$\begin{array}{l}\text { Ũ } \\
\text { Oे }\end{array}$} & & & & & $\underline{\text { RAPD- }}$ & & & & & & & & \\
\hline & 6 & 1 & 0 & 5 & 5 & 83.3 & 2345 & - & - & - & + & + & + \\
\hline & (2345- & & & & & & 942 & - & - & - & + & + & + \\
\hline & 416) & & & & & & 686 & - & - & - & + & + & + \\
\hline & & & & & & & 416 & - & - & - & + & + & + \\
\hline \multirow{2}{*}{ 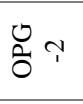 } & 8 & 6 & 2 & 2 & 0 & 25.0 & 2397 & - & - & - & - & + & - \\
\hline & $\begin{array}{c}(2397- \\
309)\end{array}$ & & & & & & 2280 & - & - & - & - & - & + \\
\hline \multirow{5}{*}{$\begin{array}{l}0 \\
0 \\
0 \\
0\end{array}$} & 7 & 1 & 2 & 6 & 4 & 85.7 & 3454 & - & - & - & + & + & - \\
\hline & (2454 & & & & & & 3357 & - & - & - & - & - & + \\
\hline & $-260)$ & & & & & & 2303 & - & - & - & + & + & \\
\hline & & & & & & & 268 & - & + & - & - & - & - \\
\hline & & & & & & & 260 & - & - & - & + & + & + \\
\hline
\end{tabular}

+: present, -: absent, Poly: polymorphism

Egypt. J. Phytopathol., Vol. 47, No. 1 (2019) 

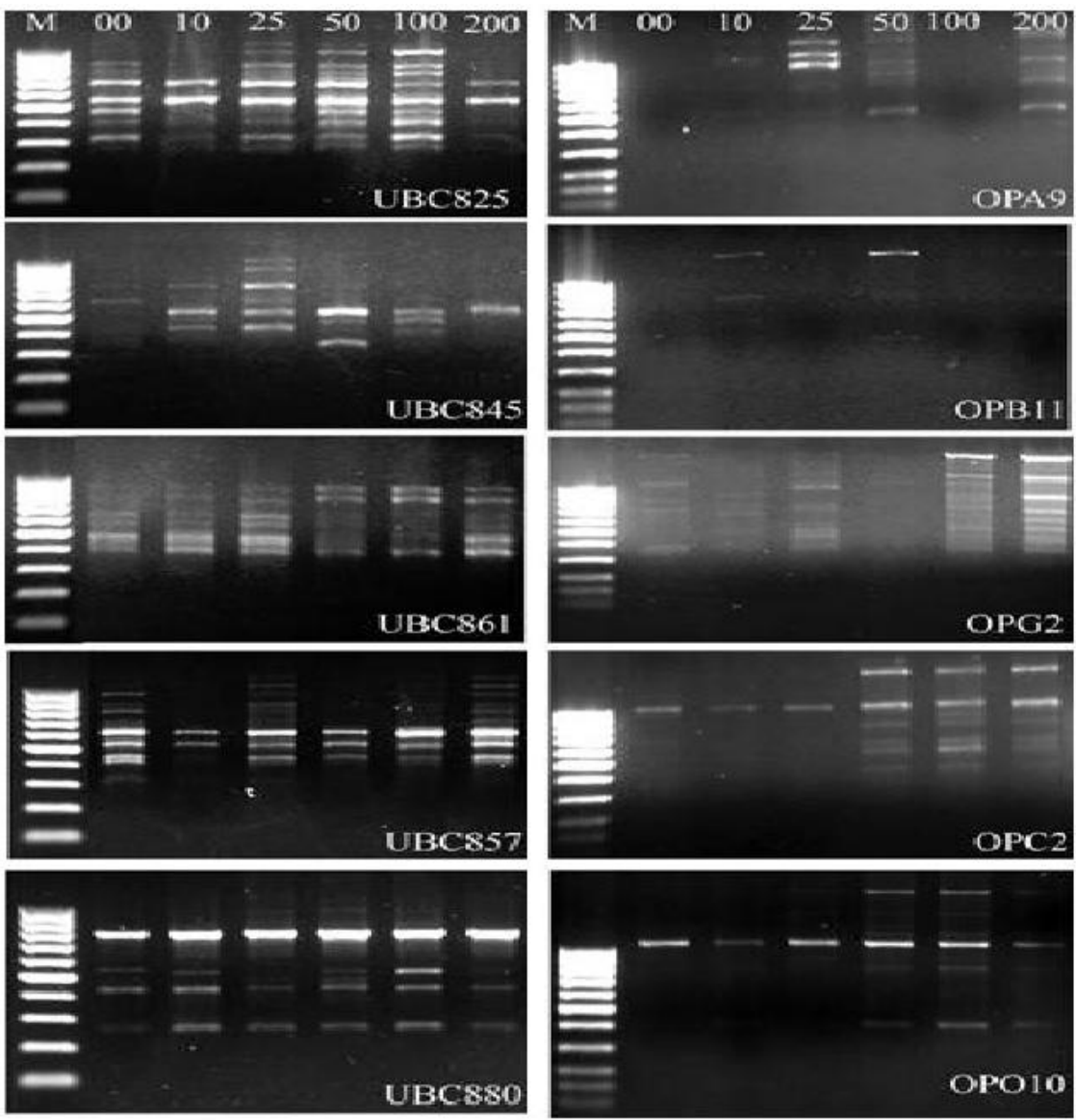

Fig (4): Agarose gel profile of genomic DNA of Magnaporthe oryzae using ISSR on the left side and RAPD-PCR markers on the right side of image. Lane numbers represent serial number of control and different concentration $(\mathrm{mg} / \mathrm{L})$ of $\mathrm{ZnO}$ NPs. $\mathrm{M}=$ molecular marker ladder $(100 \mathrm{bp})$.

\subsubsection{ISSR markers:}

The total number of bands resulted from samples DNA amplification using UBC 825 was seven bands ranged from1151 to $129 \mathrm{bp}$. Seven polymorphic with unique bands were detected. On the same text, two unique bands were detected at molecular size 135 and $131 \mathrm{bp}$ for 100 and $50 \mathrm{mg} / \mathrm{L}$, respectively. The percentage of polymorphism was $100.0 \%$. For UBC 845 primer, showed five polymorphic bands as total and ranged from 658 to $153 \mathrm{bp}$. Out of the five polymorphic bands only one 
showed unique band and detected at molecular size $153 \mathrm{bp}$, and appeared for sample treated with $50 \mathrm{mg} / \mathrm{L} \mathrm{ZnO} \mathrm{NPs.} \mathrm{The} \mathrm{percentage} \mathrm{of} \mathrm{polymorphism} \mathrm{was} 100.0 \%$.

In case of UBC 857 primer, the total number of bands was four, all of them showed monomorphic bands and ranged from 870 to $241 \mathrm{bp}$. Hence, the percentage of polymorphism was $0 \%$. For UBC 861 ISSR primer, the total number of bands was seven (three polymorphic without and four polymorphic with unique) and ranged from 1175 to $300 \mathrm{bp}$. One polymorphic unique band was detected at molecular size $300 \mathrm{bp}$, for the control (Sakha101) meanwhile was absent at all concentrations of $\mathrm{ZnO}$ NPs. All the bands were presented at molecular sizes with 1173, 993 and $837 \mathrm{bp}$ at all different concentrations of $\mathrm{ZnO}-\mathrm{NPs}$ except at $10 \mathrm{mg} / \mathrm{L}$ was absent. The percentage of polymorphism was $57 \%$.

Finally, the total number of bands obtained by using UBC 880 was 12 bands ranged from 1337 to $399 \mathrm{bp}$ (five polymorphic without and 11 polymorphic with unique). Seven unique bands were detected and out of them two unique bands were detected at molecular sizes 1337 and 994 bp at the lower concentration of ZnO-NPs $(25 \mathrm{mg} / \mathrm{L})$. Another unique band was detected at molecular size with $1337 \mathrm{bp}$ at high concentration of $\mathrm{ZnO}-\mathrm{NPs}(200 \mathrm{mg} / \mathrm{L})$. The percentage of polymorphism was $91.7 \%$.

\subsubsection{RAPD-PCR primers:}

Out of seven RAPD-PCR primers utilized in this investigation, only three primers amplified and generated polymorphic bands (OPC-2, OPG-2 and OPO-10) at all different concentrations of $\mathrm{ZnO}-\mathrm{NPs}$. The total numbers of bands obtained from samples DNA amplification using OPC-2 primer was 6 bands ranged from 2345 to $416 \mathrm{bp}$. Only one monomorphic band was detected and five were polymorphic with unique. The polymorphic unique bands were detected at molecular size with $2345,942,686,595$ and 416 bp and presented at all intermediate and high concentrations of $\mathrm{ZnO}$ NPs $(50,100$ and $200 \mathrm{mg} / \mathrm{L})$. Meanwhile, these five polymorphic bands were absent at the lower concentrations of ZnO NPs (10 and 25 $\mathrm{mg} / \mathrm{L}$ ). The polymorphism percentage was $83.33 \%$.

In case of OPG-2 primer, the total number of bands obtained was eight ranged from 2397 to $309 \mathrm{bp}$. Six monomorphic bands were detected and presented at all different concentrations of ZnO-NPs with molecular size (1522, 1028,733, 543, 451 and $309 \mathrm{bp}$ ). Two polymorphic unique bands were detected at $2397 \mathrm{bp}$ with 100 $\mathrm{mg} / \mathrm{L}$ and $2280 \mathrm{bp}$ with $200 \mathrm{mg} / \mathrm{L}$ concentration of ZnO-NPs. For OPO-10 primer, the total number of bands obtained was seven bands and ranged from 3454 to 260 bp. Two polymorphic unique bands were detected at $3357 \mathrm{bp}$ with $200 \mathrm{mg} / \mathrm{L}$ and $268 \mathrm{bp}$ with $10 \mathrm{mg} / \mathrm{L}$ concentration of $\mathrm{ZnO}$ NPs. The polymorphic with unique bands were detected at molecular size with 3454, 2303 and 787 bp presented at all intermediate and high concentrations of ZnO-NPs (50 and $100 \mathrm{mg} / \mathrm{L})$. The polymorphism percentage was $85.7 \%$.

Egypt. J. Phytopathol., Vol. 47, No. 1 (2019) 
3.7. Effect of ZnO NPs on genomic DNA of rice cultivar Sakha 101 using ISSR and RAPD-PCR markers:

In this study, genomic DNA of rice cultivar Sakha 101 was extracted and subjected to five ISSR markers and seven RAPD primers (Table 6 and Figure 5). All ISSR primers amplified and generated polymorphic alleles at all different concentrations of $\mathrm{ZnO}-\mathrm{NPs}$. On the other hand, out of seven RAPD primers used in this study, only five primers amplified and generated polymorphic bands.

Table (6): The effect of different concentrations of ZnO NPs on genomic DNA of rice cultivar Sakha101

\begin{tabular}{|c|c|c|c|c|c|c|c|c|c|c|c|c|c|}
\hline \multirow{2}{*}{ 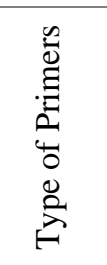 } & \multirow{2}{*}{ 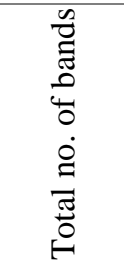 } & \multirow{2}{*}{ 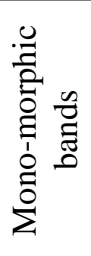 } & \multirow{2}{*}{ 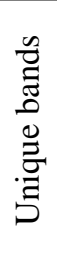 } & \multirow{2}{*}{ 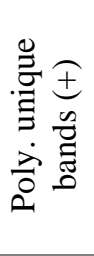 } & \multirow{2}{*}{ 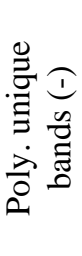 } & \multirow{2}{*}{$\frac{d}{\grave{2}}$} & \multirow{2}{*}{$\begin{array}{l}\hat{2} \\
\stackrel{3}{z} \\
\sum\end{array}$} & \multicolumn{6}{|c|}{$\begin{array}{l}\text { Concentrations of } \mathrm{ZnO} \text { NPs } \\
\qquad(\mathrm{mg} / \mathrm{L})\end{array}$} \\
\hline & & & & & & & & 0 & 10 & 25 & 50 & 100 & 200 \\
\hline \multirow{7}{*}{$\begin{array}{l}\text { ISSR } \\
\text { UBC } \\
825\end{array}$} & 9(915- & 2 & 1 & 7 & 6 & 87.5 & 915 & + & + & - & + & + & + \\
\hline & 255) & & & & & & 822 & + & + & - & + & + & + \\
\hline & & & & & & & 718 & + & + & - & + & + & + \\
\hline & & & & & & & 616 & + & + & - & + & + & + \\
\hline & & & & & & & 422 & + & + & - & + & + & + \\
\hline & & & & & & & 309 & + & + & - & + & + & + \\
\hline & & & & & & & 306 & - & - & + & - & - & - \\
\hline $\begin{array}{c}\text { UBC } \\
845\end{array}$ & $\begin{array}{c}5(915- \\
357)\end{array}$ & 4 & 1 & 1 & 0 & 20.0 & 464 & - & - & - & - & + & - \\
\hline $\begin{array}{c}\text { UBC } \\
857\end{array}$ & $\begin{array}{c}4(822- \\
243)\end{array}$ & 3 & 1 & 1 & 0 & 25.0 & 330 & + & - & - & - & - & - \\
\hline \multirow{4}{*}{$\begin{array}{c}\text { UBC } \\
861\end{array}$} & 7 (985- & 3 & 3 & 4 & 1 & 57.0 & 985 & - & - & - & + & - & - \\
\hline & 236) & & & & & & 892 & - & - & - & - & + & - \\
\hline & & & & & & & 827 & - & - & - & + & - & - \\
\hline & & & & & & & 236 & - & + & - & + & - & - \\
\hline $\begin{array}{c}\text { UBC } \\
880\end{array}$ & $\begin{array}{c}4(571- \\
260)\end{array}$ & 3 & 1 & 1 & 0 & 25.0 & 260 & - & - & - & - & - & + \\
\hline \multicolumn{14}{|c|}{ RAPD-PCR } \\
\hline \multirow{2}{*}{ OPA-9 } & 10 (1709- & 8 & 1 & 2 & 1 & 20.0 & 948 & - & + & - & - & - & - \\
\hline & 295) & & & & & & 899 & + & & + & + & + & + \\
\hline \multirow{3}{*}{$\begin{array}{c}\text { OPA- } \\
13\end{array}$} & $6(3290-$ & 3 & 1 & 3 & 2 & 50.0 & 3290 & + & - & - & + & + & + \\
\hline & 213) & & & & & & 2188 & - & - & - & - & - & + \\
\hline & & & & & & & 613 & + & - & - & + & + & + \\
\hline \multirow{5}{*}{ OPC-2 } & 5 (1156- & 0 & 0 & 5 & 5 & 100.0 & 1156 & - & + & + & + & - & - \\
\hline & 338) & & & & & & 1048 & - & - & + & + & - & - \\
\hline & & & & & & & 637 & - & + & + & + & - & - \\
\hline & & & & & & & 523 & - & + & + & + & - & - \\
\hline & & & & & & & 338 & + & + & + & + & + & - \\
\hline \multirow{2}{*}{ OPO-10 } & 2(1347- & 0 & 0 & 2 & 2 & 100.0 & 1347 & + & + & + & + & + & - \\
\hline & 1080) & & & & & & 1080 & + & + & + & + & - & - \\
\hline
\end{tabular}

+: present, -: absent, Poly: polymorphism 

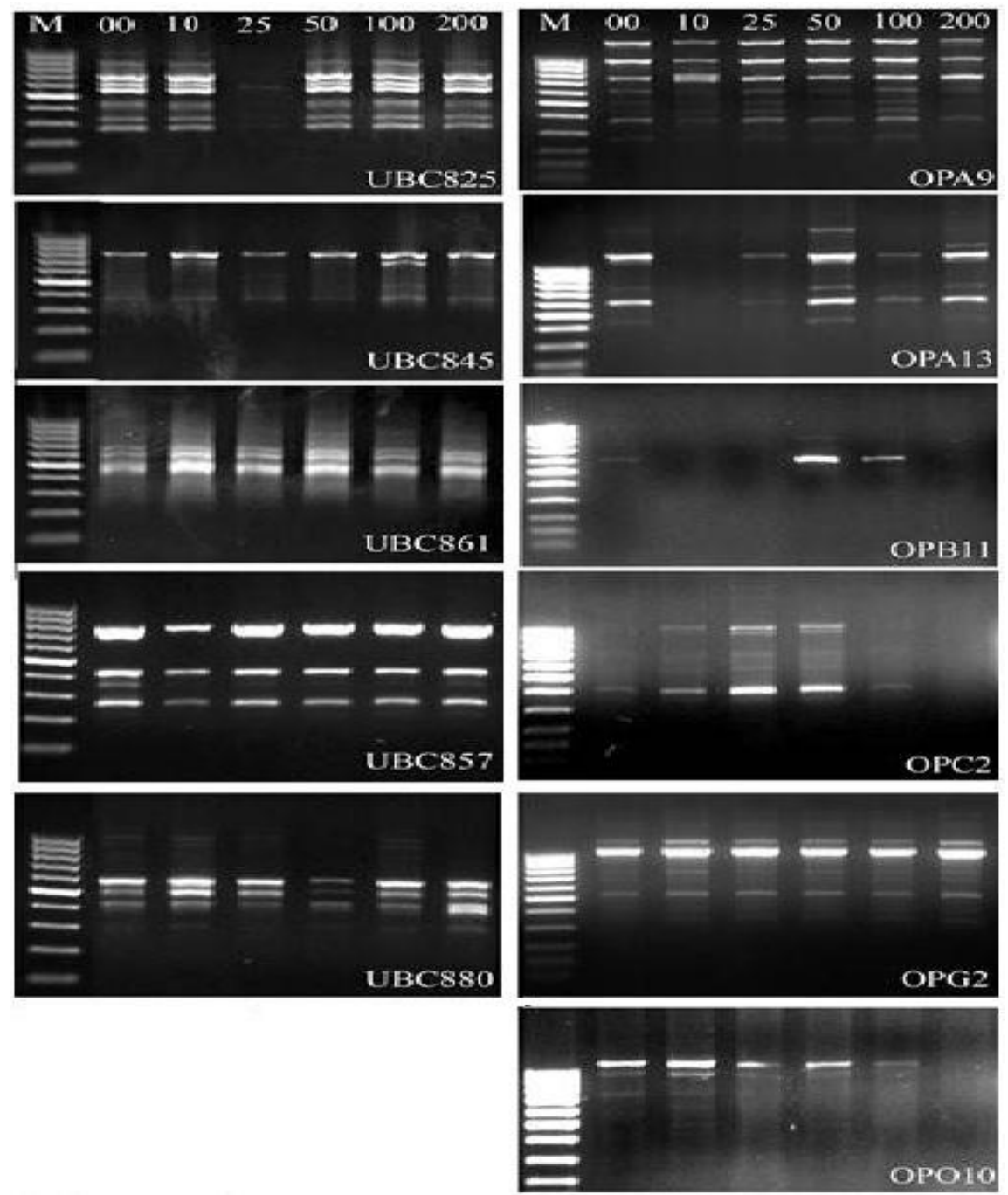

Fig (5): Agarose gel profile of genomic DNA of rice cultivar Sakha 101 using ISSR on the left side and RAPD-PCR markers on the right side of image. Lane numbers represent serial number of control and different concentration (mg/L) of $\mathrm{ZnO} \mathrm{NPs}$. M= molecular marker ladder (100 bp).

\subsubsection{ISSR markers:}

The total number of bands resulted from samples DNA amplification using UBC 825 was nine bands ranged from 915 to $255 \mathrm{bp}$. Only one unique band was detected

Egypt. J. Phytopathol., Vol. 47, No. 1 (2019) 
at molecular size $306 \mathrm{bp}$ for sample treated with $25 \mathrm{mg} / \mathrm{L} \mathrm{ZnO-NPs.} \mathrm{On} \mathrm{the} \mathrm{other}$ hand, two monomorphic bands were detected and seven polymorphic with unique bands were appeared. The percentage of polymorphism was $87.5 \%$. UBC 845 ISSR primer showed five polymorphic bands ranged from 915 to 357 bp and only one unique band was detected. The unique band was appeared at molecular size $464 \mathrm{bp}$ for sample treated with $100 \mathrm{mg} / \mathrm{L} \mathrm{ZnO-NPs.} \mathrm{In} \mathrm{primer} \mathrm{UBC} \mathrm{857,} \mathrm{the} \mathrm{total} \mathrm{bands}$ were four bands ranged from 822 to $243 \mathrm{bp}$. The three monomorphic bands were detected at molecular size 822,412 and 243 bp while the only one polymorphic unique band was detected at molecular size $330 \mathrm{bp}$, for the control (Sakha101). The percentage of polymorphism was $25 \%$. For UBC 861 ISSR primer, the total number of bands was seven (three monomorphic and four polymorphic with unique) and ranged from 985 to $236 \mathrm{bp}$. Three unique bands were detected at molecular size 985 and $827 \mathrm{bp}$ and were appeared for sample treated with $50 \mathrm{mg} / \mathrm{L} \mathrm{ZnO-NPs}$ and at 892 bp for $100 \mathrm{mg} / \mathrm{L}$. The percentage of polymorphism was $57 \%$. In case of UBC 880 , the total number of bands was four (three monomorphic and one polymorphic with unique bands) that ranged from 571 to $260 \mathrm{bp}$. A unique band at molecular size 260 bp was appeared for sample treated with $200 \mathrm{mg} / \mathrm{L} \mathrm{ZnO-NPs.}$

\subsubsection{RAPD-PCR primers:}

Out of seven RAPD-PCR primers used in this study, only five primers amplified and generated polymorphic bands (OPA-9, OPA-13, OPC-2, OPG-2 and OPO-10) at all different concentrations of ZnO-NPs. The total number of bands obtained from samples DNA amplification using OPA-9 primer was 10 bands ranged from 1709 to 295 bp. Eight monomorphic bands were detected and two were polymorphic with unique.

The unique polymorphic band was detected at molecular size $948 \mathrm{bp}$, and appeared for sample treated with $10 \mathrm{mg} / \mathrm{L} \mathrm{ZnO-NPs.} \mathrm{In} \mathrm{primer} \mathrm{OPA-13,} \mathrm{the} \mathrm{total}$ number of bands was six (three monomorphic and three polymorphic with unique) and ranged from 3290 to $213 \mathrm{bp}$. The unique polymorphic band was detected at molecular size $2188 \mathrm{bp}$, and appeared for sample treated with $200 \mathrm{mg} / \mathrm{L} \mathrm{ZnO}-\mathrm{NPs}$. The percentage of polymorphism was $50 \%$.

In case of OPC-2 primer, the total numbers of bands were five, four of them showed polymorphic with unique and ranged from 1156 to $523 \mathrm{bp}$. The unique polymorphic bands were detected at molecular size 1156, 637 and 523bp, and appeared for sample treated with lower concentrations of ZnO-NPs (10, 25 and 50 $\mathrm{mg} / \mathrm{L}$ ) respectively. On the same text, one polymorphic unique band was detected at molecular size $1048 \mathrm{bp}$ for sample treated with lower concentrations of ZnO-NPs (25 and $50 \mathrm{mg} / \mathrm{L}$ ). The percentage of polymorphism was $100 \%$. Related to OPG-2 primer, the total numbers of bands were six, all of them showed monomorphic bands and ranged from 1529 to $618 \mathrm{bp}$. Hence, the percentage of polymorphism was $0 \%$. Finally, OPO-10 primer, showed only two polymorphic bands as a total and ranged from 1347 to $1080 \mathrm{bp}$ and hence, the percentage of polymorphism was $100 \%$. 


\section{Di s c u s s i on}

Nanoparticles of different metal oxides can play important role to promote the growth and yield of plants as well as suppression of plant pathogens as a novel strategy (Petosa et al., 2017). The performance of Zn NPs was promised across the current study, it was observed that Zn NPs are more frequently associated with increases in growth and yield of rice when grown in pathogen-infection depending on concentration and time of applications. In all cases, the results were surprising given that lasting, often season-long, effect was achieved with a singular dose to young ages seedlings at nursery. These findings are extremely important for future field applications, in these small amounts of NPs could be applied under controlled and safe conditions to young seedlings, thereby reducing concerns over NPs exposure to humans and the environment.

Recently, the potential of $\mathrm{ZnO}$ for controlling pathogen growth was discussed. $\mathrm{ZnO}$ NPs are likely a more appropriate choice for fungal pathogen control than is $\mathrm{Ag}$ (Dimkpa et al., 2013). For example, ZnO NPs demonstrated higher inhibition against $F$. graminearum (Dimkpa et al., 2013), Helmenthosporium oryzae (Elamawi et al., 2016), in vitro. In a similar study, biosynthesized $\mathrm{ZnO}$ NPs $(25 \mu \mathrm{g} / \mathrm{mL})$ displayed higher inhibition rates against pathogenic bacteria and the fungal species (Jayaseelan et al., 2012). ZnO NPs significantly inhibited mycelia growth of $B$. cinerea and $P$. expansum in a plating assay (He et al., 2011). They referred theses inhibitory effects to interfering cell function and causing deformation in fungal hypha in $B$. cinerea, in addition to, inhibiting the development of conidia and conidiophores in $P$. expansum. Several mechanisms were proposed to explain the antimicrobial activity of $\mathrm{ZnO}$ NPs. The generation of hydrogen peroxide from the surface of $\mathrm{ZnO}$ NPs is considered as an effective mean for the inhibition of fungal growth. Another possible mechanism is the release of $\mathrm{Zn} 2+$ ions which can damage the cell membrane and interact with intracellular contents (Sirelkhatim et al., 2015). Navale et al., (2015) proposed that ZnO NPs and their photo catalytic properties contribute greatly to their antimicrobial activity causing structural changes of microbial cell membrane, oxidation stress and eventually the death of the cells (Sirelkhatim et al., 2015). In contrast to the present results, the stress caused by the $\mathrm{ZnO}$ NPs treatments can lead to an increase in conidia production by some fungi as mentioned by (Savi et al., 2013).

Foliar application is considered as a quick method to correct zinc unavailability and improvement resistance to plant diseases. Results under greenhouse and field conditions indicated that foliar application on young rice transplant lead to improve rice blast and yield under field conditions. ZnO NPs applied 5 DBI in artificial inoculation, nursery as well as at 25 followed by 50 DPT at concentration $25 \mathrm{mg} / \mathrm{L}$ were the most effective treatments for reducing rice blast severity. Similar results were reported by Elamawi et al., (2016) on rice brown spot disease. In contrast to this investigation, Moreira et al., (2013) found that increasing $\mathrm{Zn}$ in leaf tissues was

Egypt. J. Phytopathol., Vol. 47, No. 1 (2019) 
associated with increasing rice susceptibility to brown spot post foliar application of $\mathrm{ZnSO} 4.7 \mathrm{H} 2 \mathrm{O}$. It can be associated with the stimulation for production of nonselective toxins that become deleterious to the leaves. The mechanism of foliar uptake pathway for nanoparticles was well discussed by (Eichert et al., 2008 and Wang et al., 2013), their results revealed that the ZnO-NPs having smaller sizes could penetrate into plant leaves following the stomatal pathway, pass through different plant parts over the phloem sieve tubes. The nanoparticle size, concentration, application methods, environment conditions, and leaf structure are important factors to be considered for successful plant foliar uptake (Wang et al., 2013).

Several studies were conducted on $\mathrm{Zn}$ applications in rice crop contributing to increase grain yield under normal (Swamy et al., 2016) or salinity soil (Elamawi et al. 2016). This investigation clearly demonstrated that the ZnO NPs could be the good fertilizer and antifungal agent against pathogenic fungi that can help to avoid crop infection of $M$. oryzae.

Nanotoxicity of ZnO NPs to plants at the phytotoxicity and genotoxic level has been demonstrated by seed germination, seedling growth, isoenzyme systems, cytogenetic test (Youssef and Elamawi 2018). The results presented herein showed that, the effect of $\mathrm{ZnO}-\mathrm{NPs}$ on germination was not varied significantly between different concentrations and the control. As well as, there is no reduction in the germination percentage due to $\mathrm{ZnO}$ NPs but enhancement was observed at lower concentrations (10 and $25 \mathrm{mg} / \mathrm{L}$ ) (Fig. 1). It seems that ZnO NPs didn't affect seed germination in radish, rape, ryegrass, lettuce and cucumber except the corn seed as mentioned by Lin and Xing (2007), in soybean (López-Moreno et al., 2010) and on rice seedling (Boonyanitipong et al., 2011). In the current study, Zn NPs promoted plant growth as evidenced from improved shoot and root length at lower concentrations, while 100 and $200 \mathrm{mg} / \mathrm{L} \mathrm{ZnO} \mathrm{NPs} \mathrm{significantly} \mathrm{inhibited} \mathrm{the} \mathrm{growth}$ of rice seedlings. Similar results were reported by Bala et al., (2019) where the morphological characters as shoot and root length increased when rice seedlings were exposed to $\mathrm{ZnO}$-NPs. This improvement may be recognized to the role of zinc in cell elongation, increased antioxidant responses, membrane function, and protein synthesis. As a consequence the Zn NP treated seeds, showed better potential for germination (Upadhyaya et al., 2017).

Toxicity of $\mathrm{ZnO}$ NPs to rice seedlings specially the root growth was evident and increased with increasing concentration of ZnO NPs. This could be attributed to an excess of $\mathrm{Zn}$ ions released by the NPs as reported by Lin and Xing (2008) or to an interaction between the NPs and the root surface. The interaction of ZnO NPs with plants could be influenced by the species of plants. Lin and Xing (2008) observed that $\mathrm{ZnO}$ NPs reduced biomass, shrunk root tip and epidermis, and cortical cells became highly vacuolated and collapsed on ryegrass. Also, (Chen et al., 2015) reported that $\mathrm{ZnO}$ NPs $(250 \mathrm{mg} / \mathrm{L})$ practically reduced root and shoot length on 
ryegrass, (Boonyanitipong et al., 2011) observed reduction in number of roots and stunted the length of rice seedlings (Oryza sativa L). (Chen et al., 2015) explained that $\mathrm{ZnO}$ NPs have entered into the roots and shoots of rice seedlings. Where, dark dots in the roots and shoots under $\mathrm{ZnO}$ NPs treatment were observed and concentrated on the cell wall surface. This observation was also noticed by other researchers, $\mathrm{ZnO}$ NPs primarily adhered to root surfaces, and low upward translocation of $\mathrm{ZnO}$ NPs to shoots during the uptake of $\mathrm{ZnO}$ NPs by ryegrass (Lin and Xing 2008). In contrast, $\mathrm{ZnO}$ NPs were found to reduce seed germination in alfalfa, soybean, tomato, and cucumber at high concentration $(4000 \mathrm{mg} / \mathrm{L})$. However, corn germination was significantly reduced even at the minimum concentration of $500 \mathrm{mg} / \mathrm{L}$. ZnO-NPs at lower conc. could be used to improve seedling vigor especially for sensitive genotypes.

Results of this study indicated that ZnO NPs has the potentiality to induce synthesis as well as disappearance of protein bands. There were unique proteins at molecular weight $(120,99,89,77,72.61 \mathrm{KDa})$ in treated seeds of rice cultivar Sakha 101 at the concentrations $200 \mathrm{mg} / \mathrm{L}$ of $\mathrm{ZnO}-\mathrm{NPs}$. There are protein bands at molecular weight 63 and $60 \mathrm{KDa}$ at the concentrations of ZnO-NPs 10, 25, 50 and $100 \mathrm{mg} / \mathrm{L}$, on the other hand these bands were absent in control seeds, this occurs due to the effect of $\mathrm{ZnO}$-NPs treatment on the expression of some genes causing to it turn on to encode proteins while in the control this gene turns off. In contrast, the application of $\mathrm{ZnO}-\mathrm{NPs}$ may cause turn off to some genes while expressed in the control sample $(0 \mathrm{mg} / \mathrm{L})$, leading to the absence of some protein patterns under $\mathrm{ZnO}$ NPs treatments while presence in control condition such as the protein pattern at molecular weight $59 \mathrm{KDa}$. Proteins are main products of active structural genes expression; their size and amino acids sequence are the direct results of expression process of nucleotide sequences of the genes; hence, any observed variation in protein banding pattern induced by any mutagen is considered a mirror for genetic variations (Hamoud et al., 2005). So, alteration of protein profile could be useful for exploring the potentiality effects of pollutants or chemicals as well as nanomaterials.

The presence of these new bands may exhibit alterations in the priming sites leading to new annealing conditions in addition to homologous recombination which leads to the appearance of new bands (Atienzar and Jha 2006). Rice Sakha 101 plants were more sensitive to the effects of $\mathrm{ZnO}$ NPs as more band alterations were observed when compared to the control. The only difference between the treated and control plants were the presence or absence of $\mathrm{ZnO}-\mathrm{NP}$ which support that the changes in the DNA were caused by the effect of the $\mathrm{ZnO}$-NP. It was observed that the more effective concentrations on the plant genome were 10 and $25 \mathrm{mg} / \mathrm{L}$ compared to control.

From field experiment, the best values to improve rice grain yield and reduce leaf blast were obtained with $\mathrm{ZnO}$ NPs at a concentration of 10 and $25 \mathrm{mg} / \mathrm{L}$, this indicates that the lower concentrations of ZnO NPs (10 and $25 \mathrm{mg} / \mathrm{L})$ are considered

Egypt. J. Phytopathol., Vol. 47, No. 1 (2019) 
as a good enhancement agent in case of rice cultivar such as UBC 825 primer with $306 \mathrm{bp}$ at concentration of $25 \mathrm{mg} / \mathrm{L}$ and OPA-9 primer with $948 \mathrm{bp}$ at concentration of $10 \mathrm{mg} / \mathrm{L}$. For $M$. oryzae, the same trend of effects was appeared in case of UBC 880 primer with $994 \mathrm{bp}$ at concentration of $25 \mathrm{mg} / \mathrm{L}$ and OPO-10 primer with 268 bp at concentration of $10 \mathrm{mg} / \mathrm{L}$.

\section{Conclusions}

It can be concluded that the foliar application of $\mathrm{ZnO}$ NPs on rice cultivar Sakha101 offers a practical and useful approach to improve the performance of rice plant and increasing productivity as well as mitigate leaf blast when applied at optimal concentration and appropriate time. Biochemical and molecular markers are considered as an effective tools and evidence of enhancement effects for lower concentrations of $\mathrm{ZnO}$ NPs on rice cultivar Sakha101. Meanwhile, it showed inhibition effects on $M$. oryzae causing rice blast.

\section{References}

Atienzar, F.A. and Jha, A.N. 2006. The random amplified polymorphic DNA (RAPD) assay and related techniques applied to genotoxicity and carcinogenesis studies: A critical Review. Mutat. Res. - Rev. Mutat. Res.

Atkins, J.G.; Robert, A.L.; Adaair, C.R.; Goto, K.; Kozaka, T. and Yanagida, R. 1967. An international set of rice varieties for differentiating races of Pyricularia oryzae. Phytopathology. 57:297-301.

Bala, R.; Kalia, A. and Dhaliwal, S.S. 2019. Evaluation of efficacy of ZnO nanoparticles as remedial Zinc nanofertilizer for rice. J. Soil Sci. Plant Nutr. 19: 379-389.

Boonyanitipong, P.; Kositsup, B.; Kumar, P.; Baruah, S. and Dutta, J. 2011. Toxicity of $\mathrm{ZnO}$ and $\mathrm{TiO} 2$ nanoparticles on germinating rice seed Oryza sativa L. Int. J. Biosci. Biochem. Bioinforma., 1: 4-7.

Chen, J.; Liu, X.; Wang, C.; Yin, S. S.; Li, X.L.and Hu, W.J. 2015. Nitric oxide ameliorates zinc oxide nanoparticles-induced phytotoxicity in rice seedlings. $J$. Hazard. Mater., 297: 173-182.

Clarke, J.D. 2009. Cetyltrimethyl ammonium bromide (CTAB) DNA miniprep for plant DNA isolation. Cold Spring Harb. Protoc., 4: 5177-5179.

Couch, B.C. and Kohn, L.M. 2002. A multilocus gene genealogy concordant with host preference indicates segregation of a new species, Magnaporthe oryzae, from M. grisea. Mycologia. 94: 683-693.

Dhindwal, A.S.; Lather, B.P.S. and Singh, J. 1991. Efficacy of seed treatments ongermination. Seedling emergence and vigour of cotton (Gossypium hirsutum) genotypes. Seed Res. 19: 59. 
Dimkpa, C.O.; McLean, J.E.; Britt, D.W. and Anderson, A.J. 2013. Antifungal activity of $\mathrm{ZnO}$ nanoparticles and their interactive effect with a biocontrol bacterium on growth antagonism of the plant pathogen Fusarium graminearum. BioMetals. 26: 913-924.

Eichert, T.; Kurtz, A.; Steiner, U. and Goldbach, H.E. 2008. Size exclusion limits and lateral heterogeneity of the stomatal foliar uptake pathway for aqueous solutes and water-suspended nanoparticles. Physiol. Plant. 134: 151-160.

Elamawi, R.M. and El-Shafey, R.A. 2013. Inhibition effects of Silver nanoparticles against rice blast disease caused by Magnaporthe grisea. Egypt. J. Agric. Res., 91(4): 1271-1283

Elamawi, R.M.; Bassiouni, S.M.; Elkhoby, W.M. and Zayed, B.A. 2016. Effect of Zinc oxide nanoparticles on brown spot disease and rice productivity under saline soil. J. Plant Prot. Path. Mansoura Univ., 7(3): 171-181.

Elamawi, R.; Al-Harbi, R. and Hendi, A. 2018. Biosynthesis and characterization of silver nanoparticles using Trichoderma longibrachiatum and their effect on phytopathogenic fungi. Egypt. J. Bio. Pest Cont., 28:28.

FAO. 2009. FAO's director-general on how to feed the world in 2050. Insights from an Expert Meeting at FAO. FAO. 1:1-35.

FDA. 2011. Part 182-substances generally recognized as safe. Food and drug administration, Washington DC Available at: https://www.law.cornell.edu/cfr/text/21/part-182/subpart-I. Accessed 28 March 2011.

Gunalan, S.; Sivaraj, R. and Rajendran, V. 2012. Green synthesized ZnO nanoparticles against bacterial and fungal pathogens. Prog. Nat. Sci. Mater. Int., 22: 693-700.

Hamoud, M.A.; El-Shanshoury, A.d.; Al-Sodany, Y.M. and Gad El-Karim, M.S. 2005. Genetic diversity among Ipomoea carnea Jacq. populations from different habitat types in Nile-Delta region of Egypt. Egypt. J. Exp. Biol. (Bot.)., 1: 1-10.

He, L.; Liu, Y.; Mustapha, A. and Lin, M. 2011. Antifungal activity of zinc oxide nanoparticles against Botrytis cinerea and Penicillium expansum. Microbiol. Res., 166: 207-215.

IRRI (International Rice Research Institute) 2013. Standard Evaluation System (SES) for Rice. Los Baños (Philippines): International Rice Research Institute. Online: www.irri.org/AnnualReport/2013.pp 1066-1072.

Jayaseelan, C.; Rahuman, A.A.; Kirthi, A.V.; Marimuthu, S.; Santhoshkumar, T. and Bagavan, A. 2012. Novel microbial route to synthesize $\mathrm{ZnO}$ nanoparticles using Aeromonas hydrophila and their activity against pathogenic bacteria and fungi.

Egypt. J. Phytopathol., Vol. 47, No. 1 (2019) 
Spectrochim. Acta - Part A. Mol. Biomol. Spectrosc., 90: 78-84.

Jo, Y.K.; Kim, B.H. and Jung, G. 2009. Antifungal activity of silver ions and nanoparticles on phytopathogenic fungi. Plant Dis., 93: 1037-1043.

Kekec, G., Sakcali, M. S. and Uzonur, I. 2010. Assessment of genotoxic effects of boron on wheat (Triticum aestivum L.) and Bean (Phaseolus vulgaris L.) by using RAPD analysis. Bull. Environ. Contam. Toxicol., 84: 759-764.

Kirk, G.J.D. and Bajta, J.B. 1995. Root-induced iron oxidation, pH changes and zinc solubilization in the rhizosphere of lowland rice. New Phytol., 131: 129-137.

Kobata, T., Koç, M., Barutçular, C., Tanno, K.-i., Inagaki, M., 2018. Harvest index is a critical factor influencing the grain yield of diverse wheat species under rainfed conditions in the Mediterranean zone of southeastern Turkey and northern Syria. Plant Prod. Sci., 21: 71-82.

Kulhare, P.; Tagore, G.; and Sharma, G. 2017. Effect of foliar spray and sources of Zinc on yield, Zinc content and uptake by rice grown in a vertisol of central India. Inte J Chem. Stud., 5(2): 35-38.

Laemmli, U.K. 1970. Cleavage of structural proteins during assembly of head bacteriophage T4, () 1970 Nature Publishing Group. Nature. 227: 680-685.

Lee, S.; Chung, H.; Kim, S. and Lee, I. 2013. The genotoxic effect of $\mathrm{ZnO}$ and $\mathrm{CuO}$ nanoparticles on early growth of buckwheat, Fagopyrum esculentum. Water. Air. Soil Pollut., 224: 1668-1676

Lin, D. and Xing, B. 2007. Phytotoxicity of nanoparticles: Inhibition of seed germination and root growth. Environ. Pollut., 150: 243-250.

Lin, D., and Xing, B. 2008. Root uptake and phytotoxicity of $\mathrm{ZnO}$ nanoparticles. Environ. Sci. Technol., 42(15): 5580-5585

López-Moreno, M.L., de la Rosa, G.; Hernández-Viezcas, J.á.; Castillo-Michel, H.; Botez, C.E. and Peralta-Videa, J.R. 2010. Evidence of the differential biotransformation and genotoxicity of $\mathrm{ZnO}$ and $\mathrm{CeO}_{2}$ nanoparticles on Soybean (Glycine max) Plants. Environ. Sci. Technol. 44: 7315-7320.

Moreira, W.R.; Rodrigues, F.A. and Duarte, H.S.S. 2013. Effect of Zinc on the development of brown spot in rice. J. Phytopathol., 161: 749-751.

Nalley, L.; Tsiboe, F.; Durand-Morat, A.; Shew, A. and Thoma, G. 2016. Economic and environmental impact of rice blast pathogen (Magnaporthe oryzae) alleviation in the United States. PLoS One. 11(12): e0167295.

Navale, G.R.; Late, D.J. and Shinde, S.S. 2015. JSM Nanotechnology \& amp; Nanomedicine antimicrobial activity of $\mathrm{ZnO}$ nanoparticles against pathogenic bacteria and fungi. JSM Nanotechnol Nanomed. 3(1): 1033. 
Ou, S.H. 1985. Rice Diseases. Commonwealth Agricultural Bureaux (1985) $2^{\text {nd }}$ ed., pp. 380,

Petosa, A.R.; Rajput, F.; Selvam, O.; Öhl, C. and Tufenkji, N. 2017. Assessing the transport potential of polymeric nanocapsules developed for crop protection. Water Res., 111: 10-17.

Prasad, T.N.; Sudhakar, P.; Sreenivasulu, Y.; Latha, P.; Munaswamy, V. and Raja R.K. 2012. Effect of nanoscale zinc oxide particles on the germination, growth and yield of peanut. J. Plant Nutr., 35: 905-927.

Raliya, R. and Tarafdar, J.C. 2013. ZnO Nanoparticle biosynthesis and its effect on phosphorous-mobilizing enzyme secretion and gum contents in clusterbean (Cyamopsis tetragonoloba L.). Agric. Res., 2: 48-57.

Rasmussen, J.W.; Martinez, E.; Louka, P. and Wingett, D.G. 2011. Zinc oxide nanoparticles for selective destruction of tumor cells and potential for drug delivery applications. NIH Public Access. 7(9): 1063-1077.

Rastogi, A.; Kumar, D.; Saurabh, T.; Devendra, Y.; Chauhan, K.; and Živčák, M. 2019. Application of silicon nanoparticles in agriculture. Biotech., 9: 1-11.

Remédios, C.; Rosário, F. and Bastos, V. 2012. Environmental nanoparticles interactions with plants: morphological, physiological, and genotoxic aspects. $J$. Bot., 2012: 1-8.

Saad-Allah, K.M. and Youssef, M.S. 2018. Phytochemical and genetic characterization of five quinoa (Chenopodium quinoa Willd.) genotypes introduced to Egypt. Physiol. Mol. Biol. Plants., 24: 617-629.

Savi, G.D.; Bortoluzzi, A.J. and Scussel, V. M. 2013. Antifungal properties of Zinccompounds against toxigenic fungi and mycotoxin. Int. J. Food Sci. Technol., 48: $1834-1840$.

Sierra-Fernandez, A.; De La Rosa-García, S.C.; Gomez-Villalba, L.S.; GómezCornelio, S.; Rabanal, M.E. and Fort, R. 2017. Synthesis, photocatalytic, and antifungal properties of $\mathrm{MgO}, \mathrm{ZnO}$ and $\mathrm{Zn} / \mathrm{Mg}$ oxide nanoparticles for the protection of calcareous stone heritage. ACS Appl. Mater. Interfaces., 9: 2487324886.

Singh, N.B.; Amist, N.; Yadav, K.; Singh, D.; Pandey, J.K. and Singh, S.C. 2013. Zinc oxide nanoparticles as fertilizer for the germination, growth and metabolism of vegetable crops. J. Nanoeng. Nanomanufacturing. 3: 353-364.

Sirelkhatim, A.; Mahmud, S.; Seeni, A.; Kaus, N.H.M.; Ann, L.C. and Bakhori, S. K.M. 2015. Review on zinc oxide nanoparticles: Antibacterial activity and toxicity mechanism. Nano-Micro Lett., 7: 219-242.

Egypt. J. Phytopathol., Vol. 47, No. 1 (2019) 
Swamy, B.P.M.; Rahman, M.A.; Inabangan-Asilo, M.A.; Amparado, A.; Manito, C. and Chadha-Mohanty, P. 2016. Advances in breeding for high grain Zinc in Rice. Rice. 10: 21.

Upadhyaya, H.; Roy, H.; Shome, S.; Tewari, S. and Mk, B. 2017. Physiological impact of Zinc nanoparticle on germination of rice (Oryza sativa L) seed. J. Plant Sci Phytopath., 1: 62-70.

Wang, W.N.; Tarafdar, J.C. and Biswas, P. 2013. Nanoparticle synthesis and delivery by an aerosol route for watermelon plant foliar uptake. J. Nanopart. Res., 15: 1417.

Young, J.; Byung, K. and Geunhwa, J. 2009. Antifungal activity of silver ions and nanoparticles on phytopathogenic fungi. Plant Dis., 93: 1037-1043.

Wani, A.H. and Shah, M.A. 2012. A unique and profound effect of $\mathrm{MgO}$ and $\mathrm{ZnO}$ nanoparticles on some plant pathogenic fungi. J. Appl. Pharm. Sci., 2: 40-44.

Youssef, M.S. and Elamawi, R.M. 2018. Evaluation of phytotoxicity, cytotoxicity, and genotoxicity of $\mathrm{ZnO}$ nanoparticles in Vicia faba. Environ. Sci. Pollut. Res. Int., 27(16): 18972-18984.

Zhu, J.; Zou, Z.; Shen, Y.; Li, J.; Shi, S. and Han, S. 2019. Increased ZnO nanoparticle toxicity to wheat upon co-exposure to phenanthrene. Environ. Pollut., 247: 108-117.

Corresponding author: Elamawi, R.M.A

E-mail: rabab.elamawi@yahoo.com

(Received 24/04/2019;

in revised form 19/05/2019) 


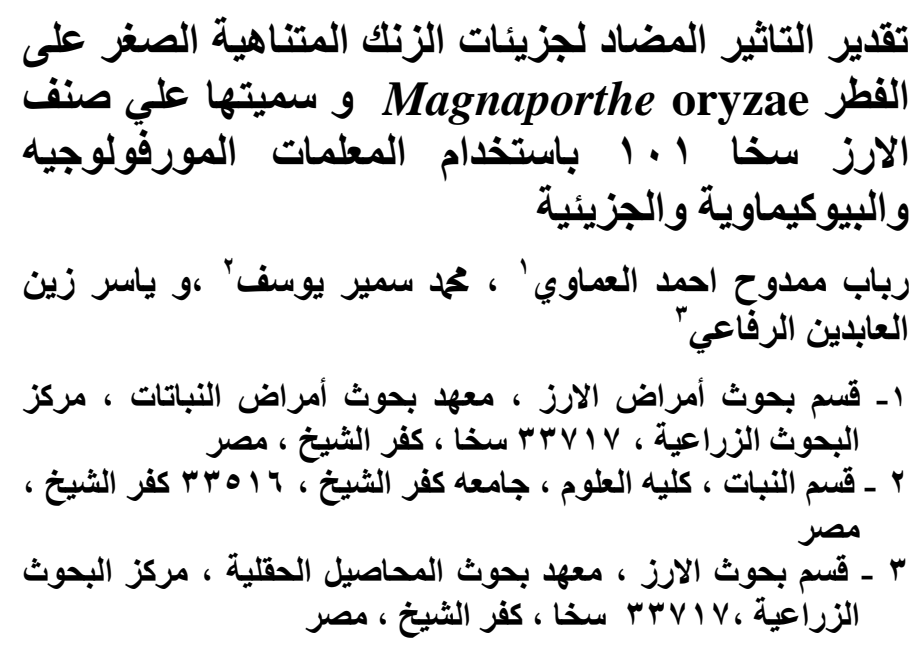

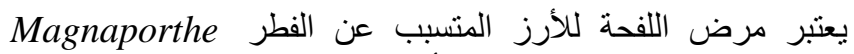
oryzae

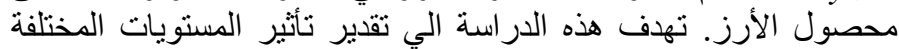

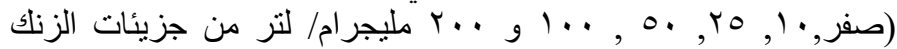

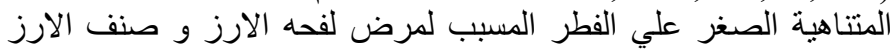
سخا 101 باستخدام المعلمات المورفولوجية و البيوكيميائية و الجزيئية.

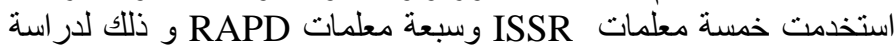
التاثيرات المحتملة لاستخدام جزيئات الزنكاتك المتتاهية الصغر ـ تم تقيبيم تأثير

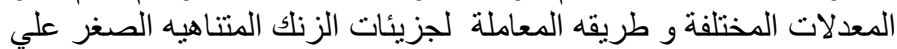

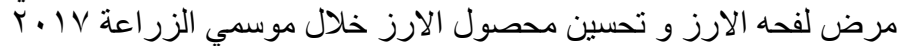

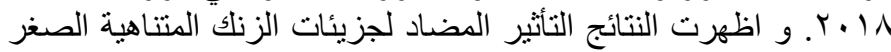

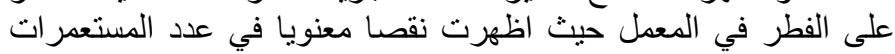

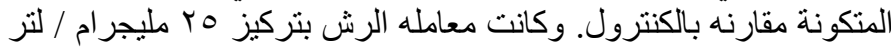

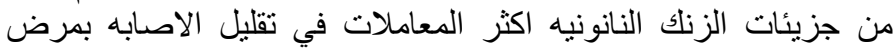

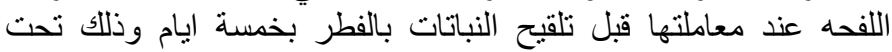

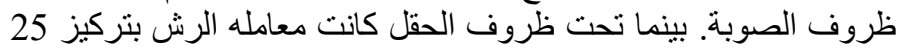

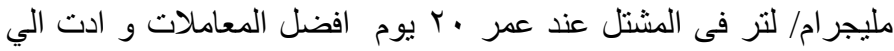

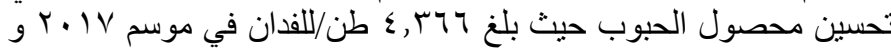

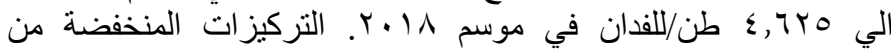

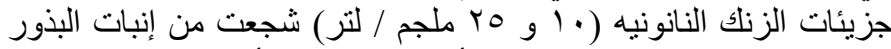

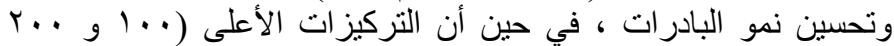

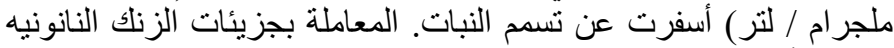

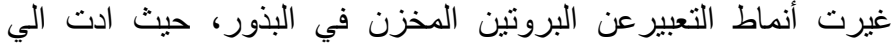

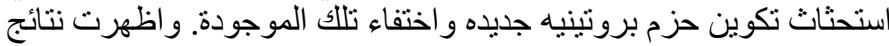

Egypt. J. Phytopathol., Vol. 47, No. 1 (2019) 


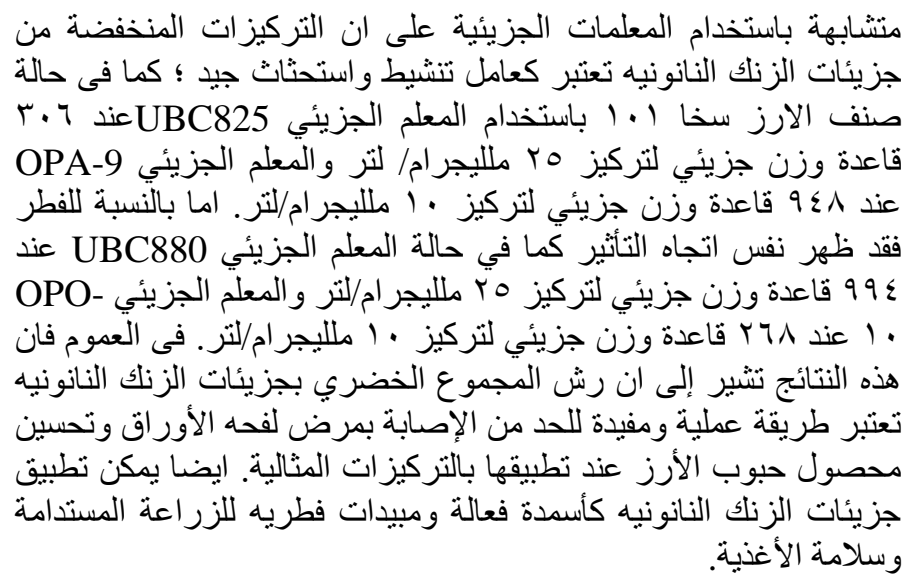

